ERC Working Papers in Economics 14/14

November/ 2014

\title{
Wage Inequality and Wage Mobility in Turkey
}

\author{
Aysit Tansel \\ Department of Economics, Middle East Technical University \\ 06800 Ankara, Turkey \\ Institute for the Study of Labor (IZA), Bonn, Germany \\ Economic Research Forum (ERF) Cairo, Egypt \\ E-mail: atansel@metu.edu.tr \\ Phone: +90 3122102073 \\ Başak Dalgıç \\ Department of Public Finance, Hacettepe University \\ 06800 Ankara, Turkey \\ E-mail: basakcakar@hacettepe.edu.tr \\ Phone: +90 3122978675 \\ Aytekin Güven \\ Department of Economics Abant İzzet Baysal University \\ 14280 Bolu, Turkey \\ E-mail: guven_a1 @ibu.edu.tr \\ Phone: +90 3742541000
}




\title{
WAGE INEQUALITY AND WAGE MOBILITY IN TURKEY*
}

\author{
Aysit Tansel** \\ Department of Economics Middle East Technical University \\ 06800 Ankara, Turkey \\ Institute for the Study of Labor (IZA), Bonn, Germany \\ Economic Research Forum (ERF) Cairo, Egypt \\ e-mail: atansel@metu.edu.tr \\ Telephone: +903122102073 \\ Fax: +90 3122107964 \\ Başak Dalgıç \\ Department of Public Finance Hacettepe University \\ 06800 Ankara, Turkey \\ e-mail: basakcakar@ hacettepe.edu.tr \\ Telephone: +90 3122978675 \\ Fax: +90 3122992063 \\ Aytekin Güven \\ Department of Economics Abant İzzet Baysal University \\ 14280 Bolu, Turkey \\ e-mail: guven_a1@ibu.edu.tr \\ Telephone: +90374254 1000 \\ Fax: +903742534521
}

\begin{abstract}
This paper investigates wage inequality and wage mobility in Turkey using the Surveys on Income and Living Conditions (SILC). This is the first paper that explores wage mobility for Turkey. It differs from the existing literature by providing analyses of wage inequality and wage mobility over various socioeconomic groups such as gender, age, education and sector of economic activity. We first present an overview of the evolution of wages and wage inequality over the period 2005-2011. Next, we compute several measures of wage mobility and explore the link between wage inequality and wage mobility. Further, we compute the transition matrices which show movements of individuals across the wage distribution from one period to another and investigate the determinants of transition probabilities using a multinomial logit model. The results show that overall the real wages increased over the study period and wage inequality exhibits a slight increase.. Wage inequality is one of the highest among the European Union (EU) countries. The wage mobility in Turkey is lower than what is observed in the European Union countries although it increases as time horizon expands. Wage mobility has an equalizing impact on the wage distribution, however; this impact is not substantial enough to overcome the high and persistent wage inequality in Turkey.
\end{abstract}

November 5, 2014

Jel Codes: D31, D63, J31, J60

Keywords: Wage Inequality, Wage Mobility, Heterogeneity, Turkey

\footnotetext{
*An earlier version of this paper is presented at the 8th Institute for the Study of Labor (IZA) and World Bank Conference on Employment and Development, August 22, 2013 in Bonn, Germany. We would like to thank the participants of this conference for their comments. Thanks are also due to Murat Karakaş head of the Labor Statistics Group and Güllü Çalık from Income and Living Conditions division both of the Statistical Institute of Turkey (TURKSTAT) for their kind help in implementing this study.

**Corresponding author.
} 


\section{Introduction}

During the last several decades wage inequality has increased susbtantially in many countries. Technological improvements and changes in the labor market structures played an important role in this increase. For example, overall wage inequality (90/10 wage ratio) rose in the USA from 3.4 in 1970 to 5.0 in 2008. Similarly, this ratio rose from 2.7 to 3.7 in the UK and from 2.4 to 3.4 in Australia during the same period. In addition, wage inequality increased also in the traditionally low inequality countries. For instance, 90/10 wage ratio increased from 2.5 to 2.9 in Germany, from 2.1 to 2.7 in Denmark during the period 19802008 and from 2.2 to 2.4 in Sweden during the period 1970-2008 (OECD, 2011). The crosssectional estimates of wage inequality ignore the role of wage mobility and do not provide any insights into whether the individuals have a chance of improving their wage position. During the last decade a growing body of literature handled the evolution of wage inequality and wage mobility together. Therefore, the purpose of this paper is to consider wage inequality and wage mobility together in Turkey.

Friedman (1962) pointed out that income mobility can equalize long-term personal incomes by promising the disadvantaged individuals of today a better position in the future. Thus, a high degree of income mobility can contribute and make the distribution of lifetime income more equal (Buchinsky and Hunt, 1999). In particular, perfect mobility of wages implies that low wage earners have the same probability as high wage earners to move to a higher wage level from one period to the next so that a low wage position would not be permanent. In such a situation wage mobility might reduce high wage inequality. However, extensive studies of wage mobility for the developed countries do not allow for general conclusions of whether wage mobility has equalizing effects on wage inequality (see among others, Dickens, 2000; Cardoso, 2006; Bachman et al., 2012). On the other hand studies of wage mobility are limited for developing countries. Although there are several studies on wage inequality in Turkey to the best of our knowledge there is no study on wage mobility in Turkey which is a developing country. Recently, Vergil (2012) and Güven et al. (2014) considered income mobility but not wage mobility in Turkey. Thus, this study plans to fill this gap. 
This study is motivated by the fact that Turkey has one of the most unequal wage distributions in the world ${ }^{1}$. We aim to contribute to the literature by exploring the evolution of wage inequality and wage mobility together for Turkey ${ }^{2}$. The contribution of our paper is twofold: First, this is the first paper investigating wage mobility for Turkey. Second it differs from the existing studies on wage mobility by providing a comprehensive analysis of wage inequality and wage mobility over various socioeconomic groups. Wage inequality and wage mobility patterns might differ for different socioeconomic groups., Therefore, we not only to present an overall picture of the evolution of wage inequality and wage mobility in Turkey but we also provide evidence on various socio economic groups such as by gender, age, education and by broad economic sectors such as industry and services ${ }^{3}$.

We use the Surveys on Income and Living Conditions (SILC) for the period 20052011 collected by TURKSTAT. We consider the wage-earners (which also includes casual workers and part-time workers) aged between 15 and 64. We use hourly real wages in cash or in kind received from the main job of the wage earner in the reference period. We use the cross section SILC data to compute the wage inequality and we use the panel feature of that data for the study period. We first present an overwiew of the evolution of wages and compute a number of wage inequality measures for Turkey. Next, in order to capture the dynamic components in wage distribution we utilize several measures of wage mobility. We extend the wage mobility analysis by composing transition matrices that show movements of individuals across quintiles from one period to another. Furthermore, we explore the determinants of the year-to-year transition probabilities using a multinomial logit model. Finally, we explore the link between wage inequality and wage mobility and test whether there is an equalizing effect of wage mobility on wage inequality.

Our main findings are as follows. Real wages increased over the 2005-2011 period but, wage inequality remains still high as compared to the other OECD countries. Wage inequality increased slightly over the study period. Wage inequality is higher for females than

\footnotetext{
${ }^{1}$ Turkey also has high income inequality. The Gini for income was 0.40 in Turkey in 2011 which is one of the largest in the world.. The same coefficient was 0.53 in Brazil, 0.48 in Mexico, 0.31 in Germany, 0.27 in Norway, 0.38 in the UK and 0.41 in the US ( World Bank, 2014).

${ }^{2}$ Wages are an important component of labor income in Turkey as it is in many countries. Total wages were the largest part of total national income with 46.5 percent in 2012 (TURKSTAT, 2013a). Further, regular and casual employees constitute the largest part of total employment with 64 percent in June 2013 (TURKSTAT, 2013b).

${ }^{3}$ Agriculture sector is excluded from the analyses due to the small number of wage-earners in Turkey in that sector.
} 
for males and higher at older ages higher among the highly educated and higher in the services than in the industry., Wage mobility in Turkey is lower compared to the European Union (EU) countries although we observe higher wage mobility at longer time horizons. In addition wage mobility has an equalizing effect on wage distribution, however; this equalizing effect is not substantial enough to overcome the high and persistent wage inequality in Turkey. We find that wage inequality is higher for women then men and it is highest for the elderly and tertiary educated and higher for the services then for the industrial economic activity. Our investigation of the wage mobility by various socioeconomic groups shows that (i) males are more mobile and more likely to move up the wage distribution compared to females, (ii) wage mobility and the probability of moving up the wage distribution declines with workers' age, (iii) wage mobility is higher among the less educated individuals as compared to higher educated and the probability of moving down the wage distribution decreases substantially as individuals become more educated, (iv) workers in the industry sector are more mobile than those in the services sector.

This paper is organized as follows: Section 2 gives a brief review of the literature. Data and methodology used are given in Section 3. Empirical results on wage inequality and wage mobility together with the determinants of mobility are discussed in Section 4. Section 5 is a digression on the labor market institutions in Turkey as possible causes of high wage inequality and low wage mobility in Turkey. Concluding remarks and policy implications are given in Section 6.

\section{Literature Review}

As remarked earlier, during he recent decades wage inequality rose in several developed countries such as the USA and the UK Further, inequality has also increased in the traditionally low inequality countries, such as Germany, Denmark and other Nordic countries (OECD 1996, 2011). In the literature two main explanations are provided for the recent increasing wage dispersion. The first explanation is known as the skill-biased technological change hypothesis (SBTC). According to SBTC hypothesis recent technological developments have increased the demand for high-skilled workers but decreased the demand for low-skilled workers. This change in demand increased the wages of high skilled labor and decreased the wages of low skilled labor and resulted in an increased wage inequality in recent decades (Katz and Murphy 1992; Card and DiNardo 2002; Acemoglu, 2002). The second explanation is about the changing labor market institutions such as employment 
protection, union density and minimum wages (Card 2001; Machin 1997; Koeniger et al. 2007; Checchi and Garcia-Penalosa, 2008). According to this approach there is a negative correlation between labor market institutions and wage inequality. Stricter employment protection laws, higher union density and higher minimum wages are associated with lower wage inequality. The literature suggests that the recent decline in labor market institutions in the developed countries contributed to the increase in wage inequality observed.

Recently, there has been a growing literature on income mobility; it is defined as the movement of workers along the income distribution. While cross sectional estimates of inequality ignore the role of income mobility, mobility of income can improve the equalization of earnings over time (Buchinsky and Hunt, 1999). Thus a high degree of income mobility can contribute to social mobility and make the distribution of lifetime income more equal. There is a vast literature on the evolution of income mobility which has controversial findings on whether mobility is increasing or decreasing over time. For instance, using Spanish Household Panel Survey data for the period 1985-1992 and various income stability indices Canto (2000) finds that the level of income mobility (Shorrocks index of mobility) in Spain has permanently increased from 1985 to 1991 and it decreased only in 1992. On the other hand, income inequality (Gini index) has declined from 0.35 to 0.30 for the full period. Kopczuk et al. (2010) explores the U.S. employment earnings (excluding self-employment) inequality and mobility between 1937 and 2004, and shows that long term earnings mobility among all workers increased after the 1950's, although short term mobility was stable over the full period in question.

Dickens (2000) uses two different data sources, the New Earning Survey and the British Household Panel Survey for the period 1975-1994 to investigate wage mobility patterns inthe UK. His results differ according to the choice of the time horizon on which mobility is defined. While the year to year mobility rates decline, mobility seems to be increase as the time period expands. Hofer and Weber (2002) investigate wage mobility in Austria for from 1986 to 1996 . Their results indicate that the degree of wage mobility is low in Austria whereas mobility rates are higher over longer periods similar to findings of Dickens. Cardoso (2006) compares wage mobility in Portugal and the UK over the period 1986 to 1999 and discusses the importance of labor market institutions such as minimum wages, employment protection legislation and collective bargaining in both countries. His results suggest that mobility declined in both countries during the period 1986-1999. Using 
the German Socio-Economic Panel for the period 1984- 2007, Gernandt (2009) explores the evolution of the wage mobility in Germany. He arranges the data in 4-year time periods and finds that wage mobility decreased between 1984/1987 and 2004/2007. Riphahn and Schnitzlein (2011) investigate the long run wage mobility patterns in Germany for the period 1975-2008. They find that while there is a significant decrease in wage mobility in East Germany in the 1990s, a slight decline in both East and West Germany is evident after the late 1990s. In a different study for Germany, Aretz (2013) examines wage mobility for the same period as Riphahn and Schnitzlein. He also finds that wage mobility decreased in the West and East Germany consistent with other studies.

Friedman (1962) introduced a debate by pointing out that income mobility might equalize long-term incomes. Several scholars explicitly tested Friedman's proposition. For instance, Buchinsky and Hunt (1999) explore wage mobility and earning distributions for the US using 1979-1991 data from the National Longitudinal Survey of Youth and show that mobility reduces wage inequality by $12 \%-26 \%$ when a four-year time horizon is considered, with similar results for annual earnings. Using European Community Household Panel (ECHP) over the period 1994-2001, Sologon and O'Donoghue (2009) find an equalizing impact of mobility on income inequality and this impact increases over time in all countries they analyze (Denmark, UK, Belgium, Greece, Ireland, Netherlands, Italy, France, Spain, Germany) except Portugal. Bachmann et al. (2012) find that mobility reduces wage inequality and the equalizing effect of mobility mainly occurs within groups using data from SILC for all EU countries as well for Norway and Iceland over the period 2004-2010. Riener (2012) examines income inequality and equalizing effect of income mobility using (ECHP) data from 1995, 1998 and 2001. He shows that there is an equalizing effect of mobility on income inequality. This equalization gets stronger when the accounting period is extended.

There are also sectoral level studies on wage mobility. For instance using income tax administrative data for the period 1993-1996, Romanov and Zussman (2003) explore wage inequality and mobility in Israil. They find that wage mobility is higher in the public sector than in the private sector. This contradicts the common view that public sector wages are more stable than those of private sector. Wage mobility is lower among men than women and wage mobility decreases as age increases. Cardoso et al. (2010) examine the wage mobility in Israel taking into account high-low concentrations in the public and private sectors. They find that private sector wage mobility exceeds that in the public sector contrary to Romanov and 
Zussman (2003). Further, wage mobility in the low concentration sub-sectors is higher than in the high concentration sub-sectors in both the private and the public sectors. Raferzeder and Winter-Ebmer (2007) analyze wage mobility using tax authority data for Austria for the period 1994-2001. They find that wage mobility is related to the starting position of the worker. Workers in large firms (more than 100 employers) have more chances to move up compared to those in small firms. Workers in the public sector, in education and health sectors have the least chances to move up.

Although there are several studies on wage dispersion in Turkey (Kara, 2006; Ilkkaracan and Selim, 2007; Tansel and Bodur, 2012 and Bakis and Polat, 2013) wage mobility has not been studied before. There are only two studies, Vergil (2012) and Güven et al. (2014), which analyze both the evolution of income inequality and income mobility for Turkey using SILC. Vergil (2012) investigates the equalizing effect of income mobility over the period 2006-2009 and compares his results with those of other countries. According to his results, income mobility in Turkey is very high compared to those of European countries and it improves income inequality. On the other hand, Güven et al. (2014) using SILC finds that income mobility raises income inequality instead of reducing it over the period 2005-2010 in Turkey.

\section{Data and Methodology}

\subsection{Data}

This study uses the data from Survey of Income and Living Conditions (SILC) collected by TURKSTAT (Turkish Statistical Institute) over the period 2006-2012 ${ }^{4}$. SILC has been carried out regularly every year since 2006 and conducted in compliance with the EU regulations. Questionnaires are formed in order to provide inforation on the target variables requested by EU Statistical Office (EUROSTAT) such as income, poverty, social exclusion and living conditions. Surveys are carried out with face to face interview technique and households are the final sampling unit which are monitored throughout four years including a panel feature in the data. The entire members of the households that live within the borders of the Republic of Turkey were included within the scope of the survey. However the

\footnotetext{
${ }^{4}$ Each survey includes information on earnings for the previous period. For example, 2006 survey reports the earnings for 2005 .
} 
populations in the elderly houses, prisons, military barracks, hospitals, hotels and child care centers as well as the immigrants were excluded from the scope of the survey.

The rotational design is used in the SILC. Accordingly, while one part of the households stays in the sampling frame from one year to another, additional new households enter the sampling frame every year. In particular, $75 \%$ of the sampling size is left in the frame of the panel, whereas $25 \%$ of the sampling size changes each year. Accordingly, panel application starts with the selection of the basic sampling which represents target population. Individuals 15 years and older are monitored throughout 4 years with the direction of the rules of monitoring-execution. The SILC provides detailed information on individual characteristics such as gender, age (grouped at five year intervals), schooling (coded in six education levels), firm size information, and sectoral (NACE Rev.1.1) classifications as well as on earnings and employment conditions.

Our unbalanced panel covers 13,360 individual wage earners (which also include casual workers and part time workers) aged between 15 and 64 over the period 2005-2011. We use hourly real wages in cash or in kind received from main job of the wage earner in income reference period. The income measure in SILC is given on an annual basis. In order to get hourly real wages we first adjust the annual wage income for inflation by using consumer price index based 2003. Next, we compute the monthly wages by dividing reported annual wages by the reported number of months spent at the main job. This is divided by 4.3 to compute the weekly real wages. Finally, weekly real wages is divided by the reported weekly hours of work in order to obtain real hourly wages. The analysis in this paper was also repeated by using monthly wages and both the inequality and the mobility results were esentailly the same. These results are available from the authors upon request.

In our analysis we exclude the agricultural workers from our sample due to low number of observations. The agricultural observations only range between 4-6\% of the total during the study period.This is consistent with the fact that there are very few wage-earners in the agricultural sector in Turkey. Further we included the causal workers in our sample since this form of wage earnership is an important activity in Turkey. The observations on causal wage-earners in our samples range between $13-20 \%$ during the study period. 


\subsection{Methodology}

To uncover the evolution of wage inequality over time different measures of inequality can be used each of which focuses on specific parts of the wage distribution. In particular there are three widely used inequality measures in the literature. The first one is percentile ratios. For instance, while the upper-tail inequality is measured by $90 / 50$ log wage differentials, lower-tail inequality is measured as 50/10 log wage differentials and the 90/10 $\log$ wage differentials indicate the overall inequality. The second inequality measure is Gini coefficient which is most sensitive to income differences in the middle of the wage distribution. Specifically, it measures the average difference between all possible pairs of wages in the population, expressed as a proportion of total earnings (see Cowell 2011):

$I_{\text {Gini }}=\frac{1}{2 N^{2} \bar{y}} \sum_{i=1}^{N} \sum_{j=1}^{N}\left|y_{i}-y_{j}\right|$

Where $y_{i}\left(y_{j}\right)$ is the income of individual $i(j), \bar{y}$ is the average income of the population and $N$ is the number of individuals in the population. The third widely used measure of inequality is the Theil coefficient that stems from the family of generalized entropy inequality measures. In contrast to Gini which is particularly sensitive to the middle of the distribution, the Theil index is sensitive to inequality at both tails of the wage distribution:

$I_{\text {Theil }}=\frac{1}{N} \sum_{i=1}^{N} \frac{y_{i}}{\bar{y}} \log \left(\frac{y_{i}}{\bar{y}}\right)$

Mean log deviation is another measure that gives disproportionate weight to inequality at the bottom of the wage distribution and calculated as

$$
I_{M L D}=\frac{1}{N} \sum_{i=1}^{N} \frac{y_{i}}{\bar{y}}
$$

Inequality measures that belong to the family of generalized entropy indices can be decomposed into different groups. This decomposition allows the exploration of inequality patterns across various subgroups of the population. Moreover, a decomposition of inequality into its between-group and within-group components allows investigating the quantitative importance of observable and unobservable characteristics of the population. The decomposition of the Theil index is defined as follows: 


$$
I_{\text {Theil }}=\frac{1}{N} \sum_{i=1}^{N} \frac{y_{i}}{\bar{y}} \log \left(\frac{y_{i}}{\bar{y}}\right)=\sum_{i=1}^{N} \frac{y_{i}}{\bar{Y}} \log \left(\frac{y_{i} N}{Y}\right)=\sum_{j} \frac{Y_{j}}{Y} \text { Theil }_{j}+\sum_{j} \frac{Y_{j}}{Y} \log \left(\frac{Y_{j} / N}{N_{j} / N}\right)
$$

where $Y$ indicates the total earnings of the whole population $Y_{j}$ is the total earnings of the subgroup, $N$ denotes the number of the individuals in total population, and $N_{j}$ is number of the individuals in the subgroup. The first part of the overall inequality in equation (4) denotes the within-group inequality and remains unexplained. Whereas, the second term represents the between-group inequality and might be attributed to the observable group characteristics. Put differently, while between-group component captures the inequality that arises from differences across subgroups, the within-group component represents the inequality that exists within the same subgroup. In this study we consider the subgroups defined by gender (men and women), by age (15-24, 25-34, 35-49, and 50-64), by education (illiterate and literate but not graduate and graduates of, primary school, middle school, high school, vocational high school and, higher education) and broad economic sectors such as, industry and services.

Cross-sectional estimates of inequality provide insights about the wage distribution at a single point in time. Since the individuals might change their position along the wagedistribution inequality measures ignore the role of the movements of workers within the wage distribution. In order to capture the dynamic components in wage distribution several mobility measures are adapted in the literature. A widely used mobility measure is Fields and Ok $(1996,1999)$ measure of mobility which is based on the total absolute log- earnings movement in a population ${ }^{5}$ :

$$
M_{F O}=\frac{1}{N} \sum_{i=1}^{N}\left|\log y_{i 1}-\log y_{i 0}\right|
$$

where $y_{i 0}$ is the base year and $y_{i 1}$ is the final yearearnings. It measures the mean percentage earnings change between two periods. The higher the value of the index the higher rate of mobility is represented by it.

Dickens (2000) develops another measure of mobility which is based on the degree of the change in ranking from one year to another:

$M_{D}=\frac{\sum_{i=1}^{N}\left|F\left(y_{i, t+1}\right)-F\left(y_{i, t}\right)\right|}{N}$

\footnotetext{
${ }^{5}$ Fields and Ok (1999) show that their measure of income mobility satisfies a set of properties namely scale invariance, symmetry, subgroup decomposability and multiplicative path separability.
} 
where $F\left(y_{i, t}\right)$ and $F\left(y_{i, t+1}\right)$ are the cumulative distribution functions for earnings in periods $t$ and $t+1$, respectively. The index takes the minimum value 0 when there is no mobility; while it takes the maximum value of 1 when there is perfect mobility i.e. earnings in the two years are perfectly negatively correlated.

The absolute mobility index of Fields and Ok (1999) does not account for the direction of mobility. Fields (2010), introduces another index testing for the equalizing effect of mobility on earnings distribution. In equation (7) below $I($.$) represents any statistical$ inequality measure as Gini coefficient, Theil index or mean log deviation, while $y_{0}$ and $\bar{y}$ stand for the initial year earnings and vector of mean earnings of the two periods respectively. The positive values of Fields (2010) index indicates that mobility has equalizing effects on inequality whereas, negative values signal for the reverse effects.

$$
M_{F 2 O 10}=1-\frac{I(\bar{y})}{I\left(y_{0}\right)}
$$

In order to put evidence on mobility patterns of individuals in terms of their positional movements in the wage distribution, individual transitions between different parts of the wage distribution throughout any two subsequent periods can also be derived. After dividing the distribution of each year into 5 quintiles, we compose transition matrices to capture the patterns of wage mobility over time. They show movements of individuals across quintiles from one period to another. By means of the transition matrices we can identify, whether, between any subsequent periods, a wage earner moves towards a higher quintile (upward transition), stays in the same quintile or moves towards a lower quintile (downward transition). We further investigate the determinants of three year-to-year transition probabilities using a multinomial logit model by considering individual characteristics such as gender, age and educational level as explanatory variables.

\section{Empirical Evidence}

\subsection{Evolution of Wages, 2005-2011}

Table 1 gives the distribution of mean hourly real wages by gender, age, education and sector of economic activity over the period 2005-2011. Mean wages are reported in Turkish Liras (TL) base 2003. The mean hourly real wages were 3.2 TL in 2005. It increased by about 
15 percent to $3.7 \mathrm{TL}$ in 2011. The increase in wages was monotonic from 2005 to 2010 except the slight decline in 2011. The male wages increased monotonically from 2005 to 2011 throughout the period. The female wages were somewhat higher than that of males in every year during 2005-2011. However a closer examination of male female wages by levels of education as shown in Table 2 indicates a higher average wages for man than for women in all education levels in all years. The male-female wage gap was small and was about 6 percent on average over the period. This may be due to the fact that a very large percentage of wageearner women in our sample were educated. The proportion of higher educated men was only about 15 percent while that of women was about 32 percent $^{6}$. We also note that when monthly wages are used male-feamal wage gap was reversed.

Table 1 also gives the distribution of real hourly wages by age groups over the 20052011 period. The lowest wages are observed for the youngest age group of 15-24 years. Wages of this age group increased by about 8 percent over the period. In each of the years wages increased over the age groups and highest wages are observed for the oldest age group of 55-64. For the 25-39 age group wages increased by about 18 percent from 2005 to 2011 . This age group experienced the largest increase in wages.

The first educational group comprises of those wage earners who are illiterate or those who are literate but do not have a diploma. This educational group clearly appears to be disadvantaged in terms of wages. First of all, their wages were the lowest compared to all other educational groups. Second, their wages declined by about 2.6 percent during 20052011 period. Third, their wages fell by about 3.7 percent from 2007 to 2008 . In 2009 it fell by about 9 percent possibly due to the global crisis before increasing by about 3.5 percent in 2010. The wages of primary school (five years of schooling) graduates are substantially higher than those of the illiterate-non graduate group. We observe only small changes from year to year, in the wages of this group with an overall decline of 1 percent during the period considered.

\footnotetext{
${ }^{6}$ Substantially higher female to male wage gap was reported in earlier studies by Kasnakoglu and Dayioglu (1997) in 1987, Dayioglu and Tunali (2003) in 1994 and Tansel (2005) in 1994. Ilkkaracan and Selim (2007) review the recent trends in gender wage gap and report that female wages was $71 \%$ of male wages in 1995 .
} 
The graduates of middle school ${ }^{7}$ have higher wages than the primary school graduates in years 2005, 2006. However, in the following five years, the wages of middle school gradutes are lower than the wages of primary school graduates. At this point we note the substantial decline by 8.3 percent during 2005-2011 for this educational group.

Next we consider the wages of high school graduates. We examine the high school graduates in two categories as general high school gradutes and vocational high school graduates $^{8}$ and the curriculum orientation of these two high school types differ. We note the significantly better position of the vocational high school gradutes in terms of their wages. First, the wages of vocational high school graduates are higher than those of the general high school graduates by about 4-17 percent over the period. Second, wages of general high school graduates declined after 2007 and the wages of the vocational high school graduates fluctuated with a decline in the crisis year of 2009. The wages of higher educated is substantially higher that of the other education levels in each of the years. Further the higher educated group experienced almost a 20 percent increase in their wages from 2005 to 2011. This is the only group which experienced an increase in wages compared to other education levels.

Finally, we consider the wages in the two main sectors of economic activity. We note that wages in the services are substantially higher than in the industry. The services/industry wage gap was about 15 percent in 2005 gradually increased over time and reached 38 percent in 2010. Further, we note that while the wages in industry declined by 2 percent from 2005 to 2010, the wages in the services increased by 18 percent. At this point we note that the employment share of agriculture was 24.6 percent in 2012, that of industry was $19.1 \%$ and that of services was 49.4 percent. In terms of employment while agricultural sector has been shrinking substantially recently, the industry sector has mostly stagnated and service sector

\footnotetext{
${ }^{7}$ Middle school involves three additional years of schooling over the primary school which is five years of schooling. The primary school (five years) was the only compulsory level of schooling until 1997. With the Educational Reform of 1997, the number of compulsory years of schooling increased from five to eight years covering the middle school. Therefore, the middle school group includes individuals who had eight years of schooling which has become compulsory in 1997.

${ }^{8}$ General high schools took mostly three years before 2005 and in the cases of foreign language general high schools they took up four years. The vocational high schools took three-four years before 2005 depending on the language of instruction. In 2005, the number of years of schooling has increased to four years in both general and vocational high schools. Recently, it was allowed to increase to five years in cases where there is an additional year of language instruction.
} 
has expanded markedly. Thus we can conclude that the service sector is a booming sector in Turkey both in terms of employment and wages.

\subsection{Wage inequality}

In this section, we first describe the evolution of the wage inequality over the period 2005-2011. In Table 3, we present various wage inequality measures. Throughout the 20052011 period we observe a slight increasing trend of inequality in wages. While there is a slight increase in Gini, Theil and MLD indices, the increase in inequality is more evident in the examination of 90/10 ratio. We note that there is a decline in overall inequality in 2006 and 2009 in all Gini, Theil and MLD indices. The 90/10 ratio which indicates the differential between the top 10 percent and the bottom 10 percent of the wage distribution shows an increase from 5.6 in 2005 to 5.9 in $2011^{9}$. The wage inequality in Turkey is higher than in most EU countries. For example, according to the OECD sources the gross earnings 90/10 ratio was 2.45 in Belgium, 3.34 in Germany, 3.70 in Portugal, 3.62 in the UK, 4.85 in Turkey and 5.04 in the US in 2011 (OECD, 2014).

The evolution of inequality at the upper and lower tails of the wage distribution can be seen by examining the 90/50 ratio and the 50/10 ratio respectively. The 90/50 ratio indicates an increasing trend in the upper tail inequality with a slight dip in 2009 which is the year of global crisis. The 50/10 ratio indicates a decreasing trend in lower tail inequality with a dip in 2006. We present a more detailed investigation of inequality patterns within the top 10 and bottom 10 percent of the wage distribution in Table 4. First of all, overall trend is stagnant in both at the top and bottom 10 percent of the wage distribution. Inequality at the top 10 percent is higher than the inequality at the bottom 10 percent by all three indices. There is a dip in inequality at the bottom 10 percent of the wage distribution in 2007 by all three indices. Although inequality at the top 10 of the wage distribution declined in 2009, the year of global crisis, by all three indices the inequality at the bottom 10 percent of the wage distribution increased during the same year by all three indices.

Table 5 shows the wage dispersion by gender. During the entire 2005-2011 period women's wage inequality is higher than that of men by all three indices. Both the female and the male wage inequality show a slight upward trend with a decline in female inequality in

\footnotetext{
${ }^{9}$ Bakis and Polat (2013) find that 90/10 wage ratio decreased over the period 2002-2010 using Household Labor Force Surveys. They investigate the possible causes of the decline in wage inequality.
} 
2009, the global crisis year, but not in male inequality. Similar observations can be seen in the evolution of the 90/10 ratio. Higher wage inequality for women than for men is also observed by Aretz (2013) in West Germany and the East Germany during the period 1975-2008 and by Franz and Steiner (2000) in East Germany during the period 1990-1997.

Table 6 shows the wage inequality by age groups. We observe that inequality becomes higher at older age groups. The highest inequality is observed for the 50-64 age group. For instance in 2011 the inequality measured by Gini index is 0.45 while it is 0.33 for the $15-24$ age group. The reason behind this finding might be the fact that in Turkey, at older agegroups the within-group qualification variation is higher. An alternative explanation might be that the marginal return of experience to an older worker might be more than that to a younger worker.

Table 7 shows inequality measures by education groups. We can say that overall inequality is lowest among the illiterates/non-graduates highest among the middle school graduates. The figures for 2011 indicate that the highest level of wage inequality is observed for the higher educated. In Turkey, education standarts show a significant variation at higher education levels and in particular there is a wide variation in the quality of high education institutions. This could be reflected in the higher inequality in wages at higher education levels.

In Table 8, we consider wage inequality in the two main sectors of economic activity. We observe that wage inequality is higher in services sector than in the industry. For example, while the Gini index is 0.34 in industry, it is 0.4 in services, in 2010.

Finally, wage inequality is decomposed into within and between group components in Table 9 which enables an analysis of the extent of wage inequality that can be explained by observable characteristics. Resuls show that within wage inequality is much larger than between wage inequality for all subgroubs showing importance of unobservable factors. This is a finding that is observed in many countries (Bachmann et al. 2012). Further Table 9 shows that there is a clear increasing trend in between group inequality by education and a decreasing trend in the between group inequality by education. 
In conclusion, there are slight increases in the inequality measures over time during the period 2005-2011. Wage inequality in Turkey with 90/10 ratio of 5.8 in 2010 is one of the highest among the OECD countries after the US and South Korea. For example, the 90/10 percentile ratio in Germany was 3.34 in 2011 and 2.81 for Denmark as the most equal country in terms of wages among the OECD countries (OECD, 2012). Thus wage inequalityin Turkey is rather high compared to traditionally low inequality countries such as Germany, Denmark and Scandinavian countries. Turkey has inequality levels similar to those of the UK, US, Brazil and Mexico. These figures show that wage inequality in Turkey is rather high compared to several countries.

\subsection{Wage Mobility}

\subsubsection{Mobility Indices}

Table 10 gives the values of Fields-Ok (1999) mobility index. As remarked earlier this index gives the absolute mobility index without regard to the direction of mobility where it ranges between 0 (no mobility) and 1 (perfect mobility). This table indicates an overall low degree of mobility as the index values mostly range around 20-30 percent. Further, we observe that there is somewhat an increase in the Fields-Ok mobility index over time i.e. the longer the time period considered the higher is the mobility. Several other researchers also found higher mobility over longer time periods such as Burkhauser et al. (1997) in Germany and the US, Hofer and Weber (2002) in Austria, Dickens (2000) in UK, Cardoso (2006) in Portugal and Aretz (2013) in East and West Germany. When we compare the index values for males and females we cannot discern a clear pattern. Excluding the age group 50-64 (which implies retired individuals as well) we observe that younger age groups are more mobile than the older age groups. Hofer and Weber (2002) also found that mobility is high for young workers in Austria between 1986 and 1996. Table 10 also shows that illiterates-not graduates are more mobile than the higher educated except during some sub-periods. Finally comparing the industry and the services sectors one cannot see a clear disparity in terms of mobility between industry and services sectors.

Dickens (2000) mobility index gives the average year-to-year mobility across the whole wage distribution, while the Fields-Ok index values in Table 10 present information about mobility taking the extension of time period into account. In Table 11 we observe more explicit patterns of mobility by means of the Dickens mobility index. Overall the very low 
numbers indicate low year-to-year wage mobility in Turkey ${ }^{10}$. In addition we observe a substantial decline in wage mobility over time. The index value in 2005-2006 period is 0.11, whereas it is 0.08 in $2010-2011$ period. When we consider mobility differences between genders we clearly observe that males are more mobile than females. This is in contrast to the findings of Dickens (2000) who found that females are slightly more mobile than males in Great Britain between 1975 and 1994. As remarked earlier the finding of Aretz in Germany with lower wage mobility for women than for men is similar to ours. Comparing the agegroups, we observe that as the age of the individuals increases mobility declines. Table 11 also shows that mobility is higher among the less educated as compared to the higher educated. In comparing the Dickens mobility index for the industry and the services sectors we conclude that indusrty sector is clearly more mobile than the services sector.

\subsubsection{Transitions between Wage Quintiles}

The mobility measures discussed in the previous section do not give information about the position of workers over time. In order to put evidence on mobility patterns of individuals in terms of their positional movements in the wage distribution, we compute the transition matrices. The transition matrices show movements of individuals across quintiles from one period to another. In other words they show the likelihood of moving up or down or staying the same along the wage distribution. We first divide the wage distribution into quintiles and next observe the movement of wage earners across quintiles from one period to the next. Two and four year quintile transitions by gender, age, education and sector of economic activity are shown in Tables 12 and 13 respectively. "Down" (up) represents those individuals who have moved to a lower (upper) quintile between two periods $t-1$ and $t$. "Same" indicates the individuals who have stayed in the same quintile.

We observe that the probability of remaining in the same quintile increases over time in both two and four-year transitions indicating a decline in mobility over time. Similar observations are found by Dickens (2000) in the UK, Hofer and Weber (2002) in Austria, Cardoso (2006) in Portugal and the UK, Gernandt (2009), Riphahn and Schnitzlein (2011) and Aretz (2013) in East and West Germany. On the other hand, a comparison of Tables 12 and 13 shows that the probability of remaining in the same quintile has decreased. This implies a higher mobility when time horizon gets longer as we consider two and four year

\footnotetext{
${ }^{10}$ Dickens (2000) index ranges between 0 (no mobility) and 1 (perfect mobility).
} 
transition matrices together. This finding is also consistent with the findings from Fields-Ok mobility measure in Table 10. Particularly, the share of individuals remaining in the same quintile ranges between 55-68 percent in two year transition matrices, while it ranges between 48-58 in four year transition matrices. Similar observations are found by Dickens (2000) in the UK, Hofer and Weber (2002) in Austria. Another result is that the probability of moving up the wage distribution is higher than the probability of moving down.

Considering the observations by gender we find that men are more likely to move along the wage distribution than women when two-year transitions and four-year transitions are considered. Furthermore, men are also more likely to move up than women. In the four year transitions the proportion of females who are moving down the wage distribution are somewhat higher than men. Similarly, Bachman et al. (2012) also found men are more likely to move up the earnings distribution than women. When we consider the age groups we can say that younger age groups (15-24 and 25-39) are more mobile than the older age groups (40-54 and 55-64). Further, the probability of moving up the wage distribution declines with workers' age. The probability of moving down the wage distribution increases for the older individuals when we consider four year transitions. These observations imply that during longer periods of time the probability of older individuals going down the wage distribution increases i.e., older indiviuals are disadvantaged over longer periods of time. Further, the highly educated individuals have substantially lowest probability of moving down the wage distribution in both two and four-year transitions. The probability of moving down the wage distribution decreases at higher education levels. In addition the negative effect of the global crisis on the illiterate/literate but not graduates can be seen clearly from 2006-2009 sub-period in Table 13. In this period 41 percent of illiterate/literate but not graduates moved downward. Finally, having a lower probability of staying in the same quintile, the industry sector is more mobile than the services sector. When we consider the direction of this mobility we observe that the probability of going down the wage distribution is substantially higher for the industry sector than for the services sector. This finding is consistent with our findings from the Dickens (2000) mobility measure.

\subsubsection{Determinants of Mobility}

In the previous section we analyzed individual mobility patterns using transition matrices. However, these matrices include limited information since they only provide descriptive evidence. In order to obtain better insights of transition dynamics at play, we 
estimate a multinomial logit model controlling for individual characteristics such as gender, age and educational level as well as working status and sector of economic activity as explanatory variables. In this model our categorical dependent variable represents year-toyear downward mobility, upward mobility and staying in the same quintile (no mobility), respectively.

Table 14 gives the estimation results for two year transition dynamics. The positive coefficient for male in upward transition indicates that males are more likely to move up the wage distribution than women while they are less likely to make a downward transition. This is consistent with the results from transition matrices where individual characteristics are not controlled for. Next, we observe that the probability of moving up the wage distribution is higher and the probability of moving down the the wage distribution is lower for the older age groups with respect to the age group 15-24, as expected. In particular, the probability of moving up the wage distribution is highest and the probability of moving down the wage distribution is lowest for the age group 35-49. This age group represents the individuals that are willing to preserve their status with high efficieny and experience regarding their working career. In terms of the educational groups we observe a more regular pattern of transition i.e. the probability of moving down the wage distribution is decreasing with workers' level of education. These results confirm similar findings from the related literature providing evidence for the effects of personal characteristics on individual mobility patterns.

When we consider sectors of economic activity, we observe that both probability of moving down and moving up the wage distribution is lower for the services with respect to the reference group of industry. Further, the probability of staying in the same quintile is higher for the services sector. These results confirm our finding above in the transition matrices that workers in the industry are more mobile compared to those in the services. Finally, results from the multinomial logit estimation show that wage earners are more stable with respect to casual workers.

\subsubsection{Mobility as an Equalizer of Wage Distribution}

In order to measure whether mobility has an equalizing effect on the wage distribution, we use Fields (2010) index. The positive value of the index refers an equalization effect whereas the negative value refers a disequalizing effect. To calculate Fields' index we utilize 
three different wage inequality measures, Gini coefficient, Theil index and MLD. According to Tablo 15 wage mobility in Turkey has an equalizing effect on wage distribution. However, compared to results for income from Vergil (2012) for Turkey and Reiner (2012) for the European countries, the index values are rather small. In addition, we cannot see a pattern of increasing effect of equalization as time period is extended which is in contrast to the results of Vergil and Reiner. Bachman et al.(2012) find that wage mobility reduces wage inequality in all the EU counries they examined.

\section{Digression on Labor Market Institutions in Turkey}

It is commonly agreed that wage distribution reflects both the supply and demand for skilled and unskilled labor and the institutional factors in the labor market. However there is no concensual position on their quantitative importance. In this section we provide a general overview of the labor market institutions which may be responsible for the high wage inequality and low wage mobility found in this paper for Turkey. Several authors such as Koeniger et al.(2004) and Bachmann et al. (2012) investigated the importance of labor market institutions such as minimum wage legislation, union density, employment protection regulation and unemployment insurance in order to explain the evolution of wage inequality in a number of EU countries. Their findings imply that labor market institutions can account for a large part of the change in wage inequality across countries. The general finding in the literature is that the stronger and more centralized unions or minimum wage legislation, employment protection, unemployment insurance benefits generosity and and its duration tend to compress the wage distribution reducing wage inequality.

Although there are rigid labor market regulations in Turkey in genral we can say that the labor markets are characterized by low degree of institutionalization. This is largely due to low enforcement of the regulations and the existence of the large informal sector which remains outside the labor market regulations. The union density is rather low in Turkey with about 5-6 percent compared to the EU average of about 23 percent and have been declining over time (OECD, 2014). The collective bargaining is considered to be noncentralized and covers only union workers. The number of workers covered by collective bargaining have been decreasing over time recently. The minimum wages relative to average wages of fulltime workers was 38 percent in Turkey, 44 percent in Australia, 43 percent in Belgium, 38 percent in Portugal 39 percent in the UK and 27 percent in the US in 2013 (OECD, 2014). 
There is no information on the extent of the workers covered by the minimum wage legislation in Turkey partly due to lack of enforcement and partly due to the large informal sector. The minimum wages increased through out the period after the almost 20 percent jump up in 2004. Güven et al. (2011) found that legal minimum wage legislation have no effect on employment in Turkey. Employment protection legislation which was recently introduced in Turkey is considered to be higher than in most countries.For instance an index for strictness of employment protection is 2.31 in Turkey, 1.81 for Belgium, 2.87 for Germany and 0.26 for the US (OECD, 2014) However employment protection in Turkey covers only large firms and most of the firms in Turkey are small or medium sized remaining outside the employment protection legislation. Unemployment Insurance system was also introduced in the early 2000s. The net replacement rate of the benefits in Turkey is around 23 percent which is lower than that in the European countries (OECD, 2014). The tax wedge in Turkey was 38.2 percent and the OECD average was 35.6 percent in 2012 (OECD, 2014). The average tax wedge has been declining in Turkey due to recent changes in legislation in the 2000s. However the large tax evation remains to be a problem in the country. In conclusion we can say that the weak institutionalization in the Turkish labor market due to the low enforcement and large informal sector may have contributed to the high wage inequality observed in Turkey. Quantifying the role of labor market institutions in high wage inequality in Turkey is beyond the scope of this paper. Further low wage mobility in Turkey could also be related to the weak institutionalization in the labor market in Turkey so that there is no institutional structure that would push the low wage workers to upper wage groups.

\section{Conclusion}

In this paper using the data from Survey on Income and Living Conditions (SILC), we examine the evolution of the wages, wage inequality and wage mobility in Turkey over the period 2005-2011. After examining the evolution of wages over time we first compute a number of overall wage inequality and wage mobility measures for various socioeconomic groups. In particular, we focus on the subgroups by gender, age and education level of individuals and broad economic sectors such as industry and services. Next, we compose transition matrices that show movements of individuals across quintiles from one period to another. Furthermore, we explore the determinants of year-to-year transition probabilities through a multinomial logit model where various individual characteristics are considered as 
explanatory variables. Finally, we test whether there is an equalizing effect of mobility on wage inequality.

Our results indicate that although the real wages increased over 2005-2011 period, s wage inequality in Turkey exhibited only a slight increasing trend. This finding suggests that the low wage group in Turkey did not benefit from wage increases. The investigation of wage dispersion by subgroups shows that female wage inequality is higher than male wage inequality. In addition, inequality becomes higher at older age groups. In terms of education groups wage inequality is lowest among the illiterates/non-graduates but highest among the higher educated. Finally, wage inequality is higher in services sector than industry. High wage inequality in Turkey could be due to weak labor market institutions together with low enforcement and large informal sector which remains outside the scope of the labor market regulations. Further high wage inequality may be acceptable is there is high wage mobility which we also consider in our analysis.

The main findings from our mobility analyses lower wage mobility in Turkey compared to the EU countries. Mobility in Turkey increases as time horizon expands consistent with the existing literature. Our exploration of wage mobility by socioeconomic groups shows that males are more mobile and more likely to move up the wage distribution compared to females. We observe that wage mobility and the probability of moving up the wage distribution declines with workers' age. In addition, mobility is higher among the less educated individuals as compared to those who are higher educated and the probability of moving down the wage distribution decreases substantially as individuals become more educated. Considering the sector of economic activity, workers in the industry sector are more mobile than those in the services sector. However, the probability of moving down the wage distribution is higher in industry than in the services. The low wage mobility in Turkey could also be due to the low degree of labor markey institutionalization so that the probability of low wage workers to move up is low.

Results from the multinomial logit estimation are consistent with several indicators of mobility we utilize throughout the paper. In particular, males are more likely to move up the wage distribution than women. The probability of moving up the wage distribution is higher for the older age groups. Moreover, we observe that the probability of moving down the wage distribution is decreasing with the workers' level of education and finally, the probability of 
staying in the same quintile is higher for the services sector. Low degree of wage mobility found in Turkey implies low degree of equality of opportunity.

Finally, we provide evidence on the equalizing effect of wage mobility on the wage distribution. However, this equalizing effect is not substantial enough to overcome the high and persistent wage inequality. In order to reduce wage inequality in Turkey, regulations to improve the wages of low wage groups should become more effective. In particular, labor market institutions should be rearranged in terms of improving union rights, unemployment protections and minimum wage legislations. In addition, considering their disadvantageous status in terms of education, the equality of opportunity should be provided for low wage groups to increase their probability of moving up the wage distribution over time.

Women are another disadvantageous group with regards to wage inequality and wage mobility in Turkey. They work with low wages and without job security and, are excluded from the labor market easily after their marriage and maternity processes. Thus women's employment should be promoted and encouraged by increasing their access to education and rearranging their rights regarding maternity. In general strengthening the labor market institutions and their enforcement and reducing the informal sector should contribute to reducing wage inequality.

\section{References}

Acemoglu, D. (2002) "Technical Change, Inequality and the Labor Market", Journal of Economic Literature, 40:7-72.

Aretz, B. (2013) "Gender Differences in German Wage Mobility". Institute for the Study of Labor (IZA), Discussion Paper, No. 7158, Bonn, Germany.

Bachmann, R., Bechara, P., Schaffner, S. (2012) "Wage Inequality and Wage Mobility in Europe". Ruhr Economic Papers, No. 386. Ruhr-Universität Bochum (RUB), Department of Economics, Bochum, Germany.

Bakis, O., Polat, S. (2013) "Wage Inequality in Turkey: 2002-2010”, Galatasaray University Economic Research Center Working Paper, No: 13-09, Istanbul, Turkey.

Buchinsky, M., Hunt, J. (1999) "Wage Mobility in the United States", The Review of Economics and Statistics, 81:351-368.

Canto, O. (2000) "Income Mobility in Spain: How Much Is There?", Review of Income and Wealth, 46:85-102. 
Card, D. (2001) "The Effect of Unions on Wage Inequality in the U.S. Labor Market", Industrial and Labor Relations Review, 54:296-315.

Card, D., DiNardo, J. E. (2002) "Skill Biased Technological Change and Rising Wage Inequality: Some Problems and Puzzles", Journal of Labor Economics, 20: 733-783.

Cardoso, A.R. (2006) "Wage Mobility: Do Institutions Make a Difference?", Labour Economics, 13: 387-404.

Cardoso, A.R., Neuman, S. and Ziderman, A. (2010) "Wage Mobility in Israel: The Effect of Sectoral Concentration", Journal of Labor Research, 31: 146-161.

Checchi, D., Garcia-Penalosa, C. (2008) "Labour Market Institutions and Income Inequality", Economic Policy, 23:601-649.

Cowell, F. (2011) Measuring Inequality, Oxford University Press, 3rd edition, Oxford, UK.

Kasnakoglu, Z., Dayioglu, M. (1997) "Women's Labor Force Participation and Earnings Differentials between Genders in Turkey", METU Studies in Development, 24: 329-361.

Dayioglu, M., Tunali, I. (2003) "Falling Behind While Catching Up: Changes in the FemaleMale Wage Differential in Urban Turkey, 1988 to 1994”, Mimeo, Department of Economics, Middle East Technical University, Ankara, Turkey.

Dickens, R. (2000) "Caught in a Trap? Wage Mobility in Great Britain: 1975-1994", Economica, 67:477-97.

Fields, G.S., Ok, E. A. (1996) "The Meaning and Measurement of Income Mobility", Journal of Economic Theory, 71: 349-377.

Fields, G.S., Ok, E.A. (1999) “Measuring Movement of Incomes”, Economica, 66: 455-472.

Fields, G.S. (2010) "Does Income Mobility Equalize Longer-term Incomes? New Measures of an Old Contept", Journal of Economic Inequality, 8: 409-427.

Franz, W., Steiner, V. (2000) "Wages in the East German Transition Process: Facts and Explanations", German Economic Review 1: 241-269.

Friedman, M. (1962) Capitalism and Freedom. Chicago University Press, Chicago.

Gernandt, J. (2009) "Decreasing Wage Mobility in Germany", ZEW Discussion Paper, No. 09-044, Mannheim, Germany.

Güven, A., Mollavelioğlu, Ş. ve Dalgıç, Ç. B. (2011) “Asgari Ücret İstihdamı Arttırır mı? 1969-2008 Türkiye Örneği (Does Minimum Wage Increase Employment? Evidence From Turkey, 1969-2008), METU Studies in Development, 38(2), p. 147-166.

Güven, A., Dalgic, B., Tansel, A. (2014) “Gelir Hareketliligi Esitsizlikleri Azaltabilir mi? Turkiye Ornegi” (Can Income Mobility Reduce Inequality), ERC Working Papers, No 1407, Middle East Technical University, Ankara, Turkey. 
Hofer, H., Weber, A. (2002) "Wage Mobility in Austria 1986-1999", Labour Economics, 9: 563-577.

Ilkkaracan, I., Selim, R. (2007) "The Gender Wage Gap in the Turkish Labor Market", LABOUR, 21: 563-593.

Kara, O. (2006) "Occupational Gender Wage Discrimination in Turkey", Journal of Economic Studies, 33:130-143.

Katz, L.F., Murphy, K.M. (1992) “Changes in Relative Wages, 1963-1987: Supply and Demand Factors”, Quarterly Journal of Economics, 107:1232-1266.

Koeniger, W., Leonardi, M., Nunziata, L. (2007) "Labour Market Institutions and Wage Inequality", Industrial and Labour Relations Review, 60: 340-356.

Kopczuk, W., Saez, E., Song, J. (2010) "Earnings Inequality and Mobility in the United States: Evidence from Social Security Data since 1937', Quarterly Journal of Economics, 125: 91-128.

Machin, S. (1997) T'he Decline of Labour Market Institutions and the Rise in Wage Inequality in Britain", European Economic Review, Papers and Proceedings, 41:647-658.

OECD (1996) Employment Outlook, available at:

http://www.oecd.org/employment/emp/oecdemploymentoutlook-downloadableeditions1989-

2011.htm

OECD (2011) Divided We Stand: Why Inequality Keeps Rising, OECD Publishing. http://dx.doi.org/10.1787/9789264119536-en.

OECD (2014) OECD.Stat Extracts. available at:

\section{http://stats.oecd.org/ (Accesed in November 2014)}

Raferzeder, T., Winter-Ebmer, R. (2007) "Who Is on the Rise in Austria: Wage Mobility and Mobility Risk", Journal of Economic Inequality, 5:39-51.

Riener, G. (2012) "Inequality and Mobility of Household Incomes in Europe: Evidence from the EHCP”, Applied Economics, 44:279-288.

Riphahn, R.T., Schnitzlein, D.D. (2011) "Wage Mobility in East and West Germany. Institute for the Study of Labor" (IZA) Discussion Paper, No. 6246, Bonn, Germany.

Romanov, D., Zussman, N. (2003) "Labor Income Mobility and Employment Mobility in Israel, 1993-1996”, Israel Economic Review, 1:81-102.

Sologon, D. M., O’Donoghue, C. (2009), "Equalizing or Disequalizing Lifetime Earnings Differentials? Earnings Mobility in the EU: 1994-2001", IZA Discussion Paper, No. 4642, Bonn, Germany.

Tansel, A. (2005) "Public-Private Employment Choice, Wage Differentials and Gender in Turkey", Economic Development and Cultural Change, 53:453-477. 
Tansel, A., Bodur, F.B. (2012) "Wage Inequality and Returns to Education in Turkey: A Quantile Regression Analysis", Review of Development Economics, 16:107-121.

TurkStat (2013a) News Bulletin: Income and Living Conditions Survey 2012, 23 September 2013, No:13594, Ankara, Turkey.

TurkStat (2013b) Household Labour Force Survey, June 2013, available at:

http://www.turkstat.gov.tr/PreHaberbultenleri.do?id=16012

Vergil, H. (2012) "Income Mobility, Income Distribution and Economic Growth in Turkey", The 32nd General Conference of The International Association for Research in Income and Wealth August 5-11, Boston, USA.

World Bank (2014) The World Bank Data Indicators, available at:

http://data.worldbank.org/indicator 
Table 1: Mean Hourly Wages (TL, Base:2003) by Gender, Age, Education and Sector, 2005-2011, Turkey

\begin{tabular}{|c|c|c|c|c|c|c|c|c|}
\hline & 2005 & 2006 & 2007 & 2008 & 2009 & 2010 & 2011 & $\begin{array}{c}\text { Change } \\
2005-2011(\%)\end{array}$ \\
\hline All & 3.201 & 3.208 & 3.433 & 3.620 & 3.660 & 3.693 & 3.667 & 14.56 \\
\hline No of Obs. & 5,807 & 5,950 & 6,495 & 6,459 & 6,761 & 8,656 & 10,447 & \\
\hline \multicolumn{9}{|l|}{ Gender: } \\
\hline Male & 3.174 & 3.172 & 3.383 & 3.561 & 3.603 & 3.619 & 3.632 & 14.44 \\
\hline Female & 3.307 & 3.353 & 3.625 & 3.835 & 3.854 & 3.944 & 3.775 & 14.16 \\
\hline M/F WageGap(\%) & -4.0 & -5.4 & -6.7 & -7.2 & -6.5 & -8.2 & -3.8 & \\
\hline \multicolumn{9}{|l|}{ Age: } \\
\hline $15-24$ & 2.024 & 1.996 & 2.218 & 2.220 & 2.277 & 2.175 & 2.194 & 8.40 \\
\hline $25-39$ & 3.037 & 3.057 & 3.263 & 3.435 & 3.511 & 3.655 & 3.572 & 17.62 \\
\hline $40-54$ & 3.707 & 3.728 & 3.996 & 4.195 & 4.104 & 4.074 & 4.072 & 9.84 \\
\hline 55-64 & 4.052 & 4.030 & 4.049 & 4.462 & 4.670 & 4.510 & 4.508 & 11.25 \\
\hline \multicolumn{9}{|l|}{ Education: } \\
\hline Illiterate/Not grad. & 1.860 & 1.791 & 1.927 & 1.856 & 1.693 & 1.752 & 1.811 & -2.64 \\
\hline Primary sch. & 2.339 & 2.270 & 2.470 & 2.484 & 2.478 & 2.393 & 2.312 & -1.17 \\
\hline Middle sch. & 2.491 & 2.395 & 2.448 & 2.384 & 2.337 & 2.230 & 2.286 & -8.25 \\
\hline Gen. high sch. & 3.267 & 3.171 & 3.304 & 3.286 & 3.127 & 3.122 & 3.099 & -5.16 \\
\hline Voc. High sch. & 3.623 & 3.290 & 3.659 & 3.631 & 3.554 & 3.656 & 3.416 & -5.70 \\
\hline V/G Wage Gap $(\%)$ & 10.9 & 3.8 & 10.7 & 10.5 & 13.7 & 17.1 & 10.3 & \\
\hline Higher Educ. & 5.562 & 5.905 & 6.077 & 6.424 & 6.441 & 6.617 & 6.632 & 19.25 \\
\hline \multicolumn{9}{|l|}{ Sector: } \\
\hline Industry & 2.896 & 2.802 & 2.893 & 3.003 & 2.887 & 2.976 & 2.843 & -1.85 \\
\hline Services & 3.321 & 3.367 & 3.643 & 3.834 & 3.914 & 3.922 & 3.927 & 18.24 \\
\hline S/I Wage Gap(\%) & 14.7 & 20.2 & 25.9 & 27.7 & 35.6 & 31.8 & 38.1 & \\
\hline
\end{tabular}

Source: Authors' computations using SILC of TURKSTAT.

Note: Due to very low number of observations (only around 100) the figures for agricultural sector are not included. 
Table 2: Mean Hourly Wages (TL, Base:2003) by Gender and Education, 2005-2011, Turkey

\begin{tabular}{cccccccccccccccc} 
& \multicolumn{2}{c}{$\mathbf{2 0 0 5}$} & \multicolumn{2}{c}{$\mathbf{2 0 0 6}$} & \multicolumn{2}{c}{$\mathbf{2 0 0 7}$} & \multicolumn{2}{c}{ 2008 } & \multicolumn{2}{c}{$\mathbf{2 0 0 9}$} & $\mathbf{2 0 1 0}$ \\
\hline Education & Male & Female & Male & Female & Male & Female & Male & Female & Male & Female & Male & Female & Male & Female \\
\hline Illiterate/Not grad. & 1.870 & 1.825 & 1.856 & 1.544 & 1.945 & 1.875 & 1.788 & 2.107 & 1.735 & 1.545 & 1.804 & 1.593 & 1.895 & 1.625 \\
Primary sch. & 2.405 & 1.970 & 2.322 & 1.937 & 2.498 & 2.289 & 2.525 & 2.242 & 2.544 & 2.126 & 2.486 & 1.876 & 2.440 & 1.750 \\
Middle sch. & 2.559 & 1.955 & 2.447 & 1.981 & 2.520 & 2.008 & 2.460 & 1.951 & 2.402 & 1.945 & 2.288 & 1.903 & 2.353 & 1.899 \\
Gen. high sch. & 3.430 & 2.754 & 3.390 & 2.486 & 3.431 & 2.892 & 3.405 & 2.877 & 3.228 & 2.823 & 3.228 & 2.815 & 3.202 & 2.778 \\
Voc. High sch. & 3.741 & 3.106 & 3.422 & 2.796 & 3.854 & 2.926 & 3.825 & 2.913 & 3.675 & 3.072 & 3.776 & 3.124 & 3.543 & 2.904 \\
Higher Educ. & 5.647 & 5.405 & 6.043 & 5.643 & 6.197 & 5.853 & 6.673 & 5.988 & 6.723 & 5.954 & 6.825 & 6.254 & 6.878 & 6.196 \\
\hline \hline
\end{tabular}

Source: Authors' computations using SILC of TURKSTAT.

Note: MLD: Mean Log Deviation 
Table 3: Various Wage Inequality Measures, 2005-2011, Turkey

\begin{tabular}{ccccccccc}
\hline \hline & 2005 & 2006 & 2007 & 2008 & 2009 & 2010 & 2011 & Overall \\
\cline { 2 - 9 } Gini & 0.388 & 0.381 & 0.386 & 0.395 & 0.389 & 0.395 & 0.396 & 0.392 \\
Theil & 0.268 & 0.259 & 0.265 & 0.276 & 0.266 & 0.279 & 0.270 & 0.272 \\
MLD & 0.256 & 0.242 & 0.248 & 0.263 & 0.256 & 0.262 & 0.261 & 0.258 \\
$90 / 10$ & 5.595 & 5.248 & 5.595 & 5.580 & 5.622 & 5.776 & 5.896 & 5.692 \\
$90 / 50$ & 2.584 & 2.592 & 2.664 & 2.723 & 2.700 & 2.792 & 3.003 & 2.750 \\
$50 / 10$ & 0.462 & 0.494 & 0.476 & 0.488 & 0.480 & 0.483 & 0.509 & 0.483 \\
\hline No. of obs. & 5.807 & 5.950 & 6.495 & 6459 & 6.761 & 8.656 & 10.447 & 50.575 \\
\hline \hline
\end{tabular}

Source: See Table 2

Note: See Table 2 
Table 4: Various Wage Inequality Measures, Top and Bottom Deciles, 2005- 2011, Turkey

\begin{tabular}{cccccccc}
\hline \hline Top10\% & 2005 & 2006 & 2007 & 2008 & 2009 & 2010 & 2011 \\
\hline Gini & & & & & & & \\
Theil & 0.213 & 0.207 & 0.201 & 0.206 & 0.197 & 0.199 & 0.173 \\
MLD & 0.098 & 0.099 & 0.096 & 0.093 & 0.084 & 0.106 & 0.068 \\
No. of obs. & 0.080 & 0.078 & 0.074 & 0.075 & 0.068 & 0.077 & 0.055 \\
\hline Bottom10\% & 579 & 594 & 649 & 645 & 676 & 865 & 1,043 \\
\hline Gini & 0.152 & 0.139 & 0.130 & 0.154 & 0.154 & 0.146 & 0.132 \\
Theil & 0.049 & 0.039 & 0.034 & 0.046 & 0.048 & 0.042 & 0.034 \\
MLD & 0.067 & 0.054 & 0.044 & 0.060 & 0.064 & 0.053 & 0.043 \\
\hline No. of obs. & 581 & 595 & 655 & 682 & 677 & 868 & 1,045 \\
\hline \hline
\end{tabular}

Source: See Table 2

Note: See Table 2 
Table 5: Various Wage Inequality Measures by Gender 2005-2011, Turkey

\begin{tabular}{cccccccccc}
\hline \hline & 2005 & 2006 & 2007 & 2008 & 2009 & 2010 & 2011 & Overall \\
\hline Male & & & & & & & & \\
Gini & 0.382 & 0.374 & 0.380 & 0.390 & 0.387 & 0.389 & 0.388 & 0.386 \\
Theil & 0.260 & 0.255 & 0.255 & 0.273 & 0.267 & 0.276 & 0.263 & 0.266 \\
MLD & 0.244 & 0.230 & 0.238 & 0.255 & 0.249 & 0.253 & 0.246 & 0.247 \\
90/10 & 5.413 & 4.982 & 5.452 & 5.435 & 5.452 & 5.490 & 5.483 & 5.445 \\
90/50 & 2.554 & 2.550 & 2.605 & 2.682 & 2.671 & 2.716 & 2.884 & 2.693 \\
50/10 & 2.119 & 1.953 & 2.092 & 2.028 & 2.041 & 2.020 & 1.901 & 2.020 \\
\hline No. of obs. & 4,638 & 4,766 & 5,146 & 5,051 & 5,217 & 6,681 & 7,935 & 39,434 \\
\hline Female & & & & & & & & \\
Gini & 0.410 & 0.402 & 0.405 & 0.407 & 0.394 & 0.410 & 0.420 & 0.410 \\
Theil & 0.298 & 0.277 & 0.298 & 0.284 & 0.261 & 0.287 & 0.293 & 0.287 \\
MLD & 0.304 & 0.287 & 0.284 & 0.289 & 0.276 & 0.292 & 0.309 & 0.295 \\
90/10 & 6.325 & 6.171 & 6.087 & 6.172 & 6.335 & 6.795 & 7.544 & 6.653 \\
90/50 & 2.632 & 2.713 & 2.818 & 2.848 & 2.733 & 2.974 & 3.244 & 2.931 \\
50/10 & 2.404 & 2.273 & 2.160 & 2.169 & 2.320 & 2.283 & 2.326 & 2.268 \\
\hline No. of obs. & 1,169 & 1,184 & 1,349 & 1,408 & 1,544 & 1,975 & 2,512 & 11,141 \\
\hline \hline
\end{tabular}

Source: See Table 2

Note: See Table 2 
Table 6: Various Wage Inequality Measures by Age Groups, 2005-2011, Turkey

\begin{tabular}{ccccccccc}
\hline \hline & 2005 & 2006 & 2007 & 2008 & 2009 & 2010 & 2011 & Overall \\
\hline 15-24 & & & & & & & & \\
Gini & 0.358 & 0.321 & 0.365 & 0.360 & 0.372 & 0.350 & 0.333 & 0.352 \\
Theil & 0.276 & 0.217 & 0.314 & 0.244 & 0.304 & 0.250 & 0.212 & 0.258 \\
MLD & 0.221 & 0.180 & 0.231 & 0.228 & 0.245 & 0.215 & 0.191 & 0.215 \\
90/10 & 4.047 & 3.673 & 4.050 & 4.803 & 4.592 & 4.426 & 4.077 & 4.172 \\
90/50 & 2.135 & 2.035 & 2.076 & 2.230 & 2.187 & 2.131 & 2.020 & 2.087 \\
50/10 & 1.894 & 1.805 & 1.949 & 2.155 & 2.101 & 2.079 & 2.016 & 2.000 \\
No. of obs. & 1,052 & 1,078 & 1,108 & 1,041 & 1,019 & 1,211 & 1,500 & 8,009 \\
\hline 25-34 & & & & & & & & \\
Gini & 0.342 & 0.344 & 0.348 & 0.368 & 0.357 & 0.376 & 0.368 & 0.362 \\
Theil & 0.198 & 0.203 & 0.209 & 0.242 & 0.218 & 0.262 & 0.228 & 0.229 \\
MLD & 0.197 & 0.197 & 0.199 & 0.223 & 0.211 & 0.233 & 0.221 & 0.216 \\
90/10 & 4.678 & 4.718 & 4.667 & 4.782 & 4.970 & 5.100 & 5.185 & 4.954 \\
90/50 & 2.303 & 2.412 & 2.452 & 2.520 & 2.627 & 2.727 & 2.824 & 2.583 \\
50/10 & 2.033 & 1.957 & 1.905 & 1.898 & 1.890 & 1.869 & 1.835 & 1.919 \\
No. of obs. & 1,993 & 2,056 & 2,335 & 2,365 & 2,446 & 3,152 & 3,669 & 18,016 \\
\hline 35-49 & & & & & & & & \\
Gini & 0.372 & 0.367 & 0.371 & 0.373 & 0.369 & 0.374 & 0.387 & 0.376 \\
Theil & 0.241 & 0.235 & 0.238 & 0.238 & 0.233 & 0.243 & 0.252 & 0.242 \\
MLD & 0.239 & 0.227 & 0.232 & 0.234 & 0.230 & 0.236 & 0.251 & 0.238 \\
90/10 & 5.347 & 5.226 & 5.325 & 5.354 & 5.300 & 5.537 & 5.812 & 5.473 \\
90/50 & 2.292 & 2.263 & 2.310 & 2.324 & 2.356 & 2.531 & 2.783 & 2.453 \\
50/10 & 2.331 & 2.309 & 2.304 & 2.304 & 2.252 & 2.188 & 2.088 & 2.232 \\
No. of obs. & 2,282 & 2,313 & 2,522 & 2,520 & 2,744 & 3,544 & 4,320 & 20,245 \\
\hline 50-64 & & & & & & & & \\
Gini & 0.458 & 0.445 & 0.437 & 0.454 & 0.449 & 0.444 & 0.446 & 0.449 \\
Theil & 0.387 & 0.371 & 0.335 & 0.386 & 0.358 & 0.342 & 0.353 & 0.361 \\
& & & & & & & &
\end{tabular}




\begin{tabular}{ccccccccc} 
MLD & 0.368 & 0.336 & 0.326 & 0.358 & 0.358 & 0.350 & 0.347 & 0.350 \\
$90 / 10$ & 7.274 & 6.751 & 7.382 & 7.366 & 7.878 & 7.745 & 7.825 & 7.483 \\
$90 / 50$ & 2.831 & 2.846 & 2.987 & 2.800 & 2.831 & 2.801 & 2.952 & 2.903 \\
$50 / 10$ & 2.571 & 2.370 & 2.469 & 2.632 & 2.786 & 2.762 & 2.653 & 2.577 \\
No. of obs. & 480 & 503 & 530 & 533 & 552 & 749 & 958 & 4,305 \\
\hline \hline
\end{tabular}

Source: See Table 2

Note: See Table 2 
Table 7: Various Wage Inequality Measures by Education, 2005-2011, Turkey

\begin{tabular}{|c|c|c|c|c|c|c|c|c|}
\hline & 2005 & 2006 & 2007 & 2008 & 2009 & 2010 & 2011 & Overall \\
\hline \multicolumn{9}{|c|}{ Illiterate/Not grad. } \\
\hline Gini & 0.332 & 0.283 & 0.317 & 0.298 & 0.274 & 0.262 & 0.292 & 0.295 \\
\hline Theil & 0.212 & 0.142 & 0.207 & 0.175 & 0.131 & 0.115 & 0.151 & 0.162 \\
\hline$M L D$ & 0.191 & 0.141 & 0.179 & 0.162 & 0.132 & 0.114 & 0.142 & 0.151 \\
\hline $90 / 10$ & 3.693 & 3.375 & 3.448 & 3.600 & 3.467 & 2.963 & 3.558 & 3.458 \\
\hline $90 / 50$ & 2.083 & 1.875 & 1.864 & 1.837 & 1.694 & 1.736 & 1.869 & 1.846 \\
\hline $50 / 10$ & 1.773 & 1.799 & 1.848 & 1.961 & 2.045 & 1.706 & 1.905 & 1.873 \\
\hline No. of obs. & 294 & 261 & 307 & 259 & 246 & 361 & 482 & 2,210 \\
\hline \multicolumn{9}{|l|}{ Primary sch. } \\
\hline Gini & 0.329 & 0.288 & 0.305 & 0.314 & 0.298 & 0.282 & 0.271 & 0.297 \\
\hline Theil & 0.191 & 0.144 & 0.168 & 0.193 & 0.160 & 0.141 & 0.129 & 0.160 \\
\hline$M L D$ & 0.186 & 0.139 & 0.155 & 0.166 & 0.152 & 0.135 & 0.123 & 0.150 \\
\hline $90 / 10$ & 4.315 & 3.417 & 3.573 & 3.654 & 3.750 & 3.417 & 3.281 & 3.588 \\
\hline $90 / 50$ & 2.265 & 1.961 & 2.007 & 2.098 & 2.016 & 1.929 & 1.879 & 2.013 \\
\hline $50 / 10$ & 1.905 & 1.742 & 1.779 & 1.742 & 1.859 & 1.770 & 1.745 & 1.783 \\
\hline No. of obs. & 2,146 & 2,112 & 2,185 & 1,993 & 1,951 & 2,505 & 2,950 & 15,842 \\
\hline \multicolumn{9}{|l|}{ Middle sch. } \\
\hline Gini & 0.371 & 0.340 & 0.350 & 0.349 & 0.335 & 0.310 & 0.303 & 0.334 \\
\hline Theil & 0.251 & 0.204 & 0.222 & 0.221 & 0.241 & 0.169 & 0.160 & 0.205 \\
\hline$M L D$ & 0.233 & 0.194 & 0.204 & 0.215 & 0.203 & 0.169 & 0.159 & 0.192 \\
\hline $90 / 10$ & 5.016 & 4.500 & 4.526 & 5.139 & 4.149 & 4.069 & 4.040 & 4.418 \\
\hline $90 / 50$ & 2.411 & 2.476 & 2.312 & 2.350 & 2.092 & 2.067 & 2.106 & 2.242 \\
\hline $50 / 10$ & 2.079 & 1.818 & 1.957 & 2.188 & 1.984 & 1.969 & 1.919 & 1.972 \\
\hline No. of obs. & 870 & 922 & 1,009 & 974 & 1,042 & 1,363 & 1,692 & 7,872 \\
\hline \multicolumn{9}{|l|}{ Gen. high sch. } \\
\hline Gini & 0.348 & 0.336 & 0.339 & 0.325 & 0.308 & 0.313 & 0.325 & 0.327 \\
\hline Theil & 0.217 & 0.190 & 0.197 & 0.177 & 0.159 & 0.161 & 0.179 & 0.182 \\
\hline
\end{tabular}




\begin{tabular}{ccccccccc} 
MLD & 0.199 & 0.190 & 0.190 & 0.174 & 0.159 & 0.161 & 0.171 & 0.177 \\
$90 / 10$ & 4.667 & 4.727 & 4.625 & 4.404 & 3.979 & 4.250 & 4.269 & 4.350 \\
$90 / 50$ & 2.245 & 2.083 & 2.232 & 2.124 & 2.067 & 2.166 & 2.371 & 2.189 \\
50/10 & 2.079 & 2.268 & 2.075 & 2.075 & 1.927 & 1.961 & 1.802 & 1.988 \\
No. of obs. & 732 & 778 & 865 & 864 & 891 & 1,046 & 1,214 & 6,390 \\
\hline Voc. High sch. & & & & & & & & \\
\hline Gini & 0.351 & 0.337 & 0.351 & 0.325 & 0.318 & 0.333 & 0.320 & 0.333 \\
Theil & 0.226 & 0.203 & 0.225 & 0.179 & 0.185 & 0.228 & 0.167 & 0.200 \\
MLD & 0.207 & 0.190 & 0.205 & 0.172 & 0.168 & 0.188 & 0.167 & 0.184 \\
$90 / 10$ & 5.143 & 4.603 & 4.573 & 4.384 & 3.841 & 4.104 & 4.349 & 4.350 \\
90/50 & 2.180 & 2.219 & 2.223 & 2.253 & 2.114 & 2.154 & 2.297 & 2.206 \\
50/10 & 2.358 & 2.075 & 2.058 & 1.946 & 1.818 & 1.905 & 1.894 & 1.972 \\
No. of obs. & 699 & 739 & 808 & 869 & 925 & 1,126 & 1,327 & 6,493 \\
\hline Higher educ. & & & & & & & & \\
Gini & 0.310 & 0.31027 & 0.299 & 0.314 & 0.318 & 0.299 & 0.296 & 0.305 \\
Theil & 0.177 & 0.182 & 0.174 & 0.181 & 0.185 & 0.169 & 0.157 & 0.170 \\
MLD & 0.166 & 0.171 & 0.162 & 0.175 & 0.168 & 0.163 & 0.162 & 0.166 \\
90/10 & 4.048 & 3.990 & 3.887 & 4.295 & 3.841 & 4.008 & 4.579 & 4.170 \\
90/50 & 1.958 & 1.792 & 1.763 & 1.851 & 2.114 & 1.675 & 1.729 & 1.767 \\
50/10 & 2.066 & 2.227 & 2.203 & 2.320 & 1.818 & 2.392 & 2.646 & 2.358 \\
No. of obs. & 1,066 & 1,138 & 1,321 & 1,500 & 1,706 & 2,255 & 2,782 & 11,768 \\
\hline \hline
\end{tabular}

Source: See Table 2

Note: See Table 2 
Table 8: Various Wage Inequality Measures by Sector of Economic Activity, 2005-2011,

Turkey.

\begin{tabular}{ccccccccc}
\hline \hline & 2005 & 2006 & 2007 & 2008 & 2009 & 2010 & 2011 & Overall \\
\hline Industry & & & & & & & & \\
Gini & 0.379 & 0.357 & 0.345 & 0.364 & 0.333 & 0.343 & 0.331 & 0.350 \\
Theil & 0.269 & 0.263 & 0.219 & 0.260 & 0.220 & 0.283 & 0.213 & 0.246 \\
MLD & 0.250 & 0.221 & 0.200 & 0.226 & 0.195 & 0.206 & 0.189 & 0.211 \\
$90 / 10$ & 5.014 & 4.063 & 4.333 & 4.463 & 3.905 & 3.796 & 3.967 & 4.198 \\
90/50 & 2.649 & 2.293 & 2.437 & 2.508 & 2.192 & 2.229 & 2.310 & 2.359 \\
50/10 & 1.894 & 1.773 & 1.776 & 1.779 & 1.783 & 1.704 & 1.718 & 1.779 \\
No. of obs. & 1,643 & 1,676 & 1816 & 1,657 & 1,668 & 2,092 & 2,505 & 13,057 \\
\hline Services & & & & & & & & \\
Gini & 0.388 & 0.383 & 0.393 & 0.396 & 0.394 & 0.399 & 0.401 & 0.397 \\
Theil & 0.266 & 0.254 & 0.273 & 0.274 & 0.267 & 0.270 & 0.273 & 0.271 \\
MLD & 0.256 & 0.246 & 0.259 & 0.268 & 0.265 & 0.272 & 0.273 & 0.266 \\
90/10 & 5.767 & 5.481 & 5.885 & 5.812 & 6.035 & 6.323 & 6.369 & 6.045 \\
90/50 & 2.503 & 2.512 & 2.590 & 2.616 & 2.654 & 2.763 & 2.935 & 2.694 \\
50/10 & 2.304 & 2.183 & 2.273 & 2.222 & 2.273 & 2.288 & 2.169 & 2.242 \\
No. of obs. & 4,164 & 4,274 & 4,679 & 4,802 & 5,093 & 6,564 & 7,942 & 37,518 \\
\hline \hline Source: See Table 2 & & & & & & &
\end{tabular}

Source: See Table 2

Note: See Table 2 
Table 9: Decomposition of Wage Inequality by Gender, Age, Education and Sector

\begin{tabular}{|c|c|c|c|c|c|c|c|}
\hline & 2005 & 2006 & 2007 & 2008 & 2009 & 2010 & 2011 \\
\hline \multicolumn{8}{|l|}{ Gender } \\
\hline Between-group inequality by gender & 0.0001 & 0.0003 & 0.0004 & 0.0005 & 0.0004 & 0.0007 & 0.0001 \\
\hline $\begin{array}{c}\text { Within-group inequality by gender } \\
\text { Age }\end{array}$ & 0.2682 & 0.2592 & 0.2645 & 0.2759 & 0.2654 & 0.2784 & 0.2701 \\
\hline Between-group inequality by Age & 0.0219 & 0.0228 & 0.0189 & 0.0213 & 0.0185 & 0.0180 & 0.0183 \\
\hline Within-group inequality by Age & 0.2464 & 0.2367 & 0.2460 & 0.2552 & 0.2474 & 0.2611 & 0.2519 \\
\hline \multicolumn{8}{|l|}{ Education } \\
\hline Between-group inequality by Education & 0.0659 & 0.0816 & 0.0765 & 0.0900 & 0.0959 & 0.1096 & 0.1146 \\
\hline $\begin{array}{c}\text { Within-group inequality by Education } \\
\text { Sector }\end{array}$ & 0.2024 & 0.1779 & 0.1883 & 0.1865 & 0.1699 & 0.1695 & 0.1556 \\
\hline Between-group inequality by Sector & 0.0018 & 0.0032 & 0.0050 & 0.0052 & 0.0077 & 0.0063 & 0.0084 \\
\hline Within-group inequality by Sector & 0.2665 & 0.2562 & 0.2599 & 0.2712 & 0.2581 & 0.2728 & 0.2618 \\
\hline
\end{tabular}

Source: See Table 2 
Table 10: Fields-Ok (1999) Mobility Index by Gender, Age, Education and Sector, 2005-2011, Turkey (\%)

\begin{tabular}{|c|c|c|c|c|c|c|c|c|c|c|c|c|}
\hline & $\begin{array}{l}2005- \\
2006 \\
\end{array}$ & $\begin{array}{l}2005- \\
2007 \\
\end{array}$ & $\begin{array}{l}2005- \\
2008 \\
\end{array}$ & $\begin{array}{l}2006- \\
2007 \\
\end{array}$ & $\begin{array}{l}2006- \\
2008 \\
\end{array}$ & $\begin{array}{l}2006- \\
2009 \\
\end{array}$ & $\begin{array}{l}2007- \\
2008 \\
\end{array}$ & $\begin{array}{r}2007- \\
2009 \\
\end{array}$ & $\begin{array}{l}2007- \\
2010 \\
\end{array}$ & $\begin{array}{l}2008- \\
2009 \\
\end{array}$ & $\begin{array}{l}2008- \\
2010 \\
\end{array}$ & $\begin{array}{l}2008- \\
2011 \\
\end{array}$ \\
\hline All & 0.2692 & 0.3057 & 0.3343 & 0.2228 & 0.2783 & 0.2792 & 0.2302 & 0.2681 & 0.2883 & 0.2163 & 0.2557 & 0.2845 \\
\hline \multicolumn{13}{|l|}{ Gender } \\
\hline Male & 0.2700 & 0.3040 & 0.3343 & 0.2247 & 0.2824 & 0.2825 & 0.2285 & 0.2718 & 0.2862 & 0.2115 & 0.2505 & 0.2828 \\
\hline Female & 0.2654 & 0.3138 & 0.3288 & 0.2148 & 0.2606 & 0.2661 & 0.2364 & 0.2543 & 0.2976 & 0.2336 & 0.2747 & 0.2904 \\
\hline \multicolumn{13}{|l|}{ Age } \\
\hline $15-24$ & 0.3329 & 0.4095 & 0.4563 & 0.2734 & 0.3663 & 0.3383 & 0.2747 & 0.3235 & 0.3290 & 0.2821 & 0.3083 & 0.3619 \\
\hline $25-34$ & 0.2634 & 0.3016 & 0.3338 & 0.2153 & 0.2841 & 0.2844 & 0.2412 & 0.2672 & 0.2879 & 0.2105 & 0.2650 & 0.2994 \\
\hline $35-49$ & 0.2491 & 0.2749 & 0.3038 & 0.2174 & 0.2493 & 0.2492 & 0.2046 & 0.2518 & 0.2759 & 0.1952 & 0.2298 & 0.2526 \\
\hline $50-64$ & 0.2881 & 0.3239 & 0.3045 & 0.1949 & 0.2566 & 0.3462 & 0.2503 & 0.2817 & 0.3006 & 0.2473 & 0.2761 & 0.2809 \\
\hline \multicolumn{13}{|l|}{ Education } \\
\hline $\begin{array}{c}\text { Illiterate/Not } \\
\text { grad. }\end{array}$ & 0.3136 & 0.2943 & 0.2531 & 0.2272 & 0.2598 & 0.3080 & 0.2900 & 0.3174 & 0.3930 & 0.2400 & 0.2634 & 0.2749 \\
\hline Primary sch. & 0.2947 & 0.3207 & 0.3530 & 0.2354 & 0.2913 & 0.3033 & 0.2360 & 0.2855 & 0.2840 & 0.2436 & 0.2625 & 0.2971 \\
\hline Middle sch. & 0.2911 & 0.3461 & 0.3449 & 0.2452 & 0.2885 & 0.3134 & 0.2598 & 0.2881 & 0.2930 & 0.2375 & 0.2531 & 0.3041 \\
\hline Gen. high sch. & 0.2521 & 0.2657 & 0.3361 & 0.2091 & 0.2893 & 0.2300 & 0.2077 & 0.2284 & 0.2784 & 0.1930 & 0.2507 & 0.3054 \\
\hline Voc. High sch. & 0.2354 & 0.2923 & 0.3182 & 0.2328 & 0.2750 & 0.2612 & 0.2244 & 0.2676 & 0.2700 & 0.2041 & 0.2512 & 0.2646 \\
\hline Higher Educ. & 0.2298 & 0.2882 & 0.3234 & 0.1889 & 0.2520 & 0.2641 & 0.2130 & 0.2534 & 0.2912 & 0.1907 & 0.2532 & 0.2656 \\
\hline \multicolumn{13}{|l|}{ Sector } \\
\hline Industry & 0.2596 & 0.2857 & 0.3005 & 0.2474 & 0.2845 & 0.2513 & 0.2314 & 0.2825 & 0.2732 & 0.2219 & 0.2596 & 0.3058 \\
\hline Services & 0.2731 & 0.3138 & 0.3469 & 0.2134 & 0.2762 & 0.2874 & 0.2299 & 0.2632 & 0.2941 & 0.2145 & 0.2544 & 0.2783 \\
\hline No. of $O b s$. & 3,262 & 1,813 & 770 & 3,579 & 948 & 986 & 2,503 & 2,045 & 923 & 3,799 & 2,171 & 882 \\
\hline
\end{tabular}

Source: See Table 2 
Table 11: Dickens (2000) Mobility Index by Gender, Age, Education and Sector, 2005-2011, Turkey

\begin{tabular}{|c|c|c|c|c|c|c|}
\hline & $2005-2006$ & $2006-2007$ & $2007-2008$ & $2008-2009$ & $2009-2010$ & 2010-2011 \\
\hline All & 0.1110 & 0.0915 & 0.0923 & 0.0884 & 0.0775 & 0.0764 \\
\hline \multicolumn{7}{|l|}{ Gender } \\
\hline Male & 0.1149 & 0.0947 & 0.0942 & 0.0895 & 0.0790 & 0.0812 \\
\hline Female & 0.0974 & 0.0811 & 0.0873 & 0.0872 & 0.0746 & 0.0640 \\
\hline \multicolumn{7}{|l|}{ Age } \\
\hline $15-24$ & 0.1763 & 0.1356 & 0.1333 & 0.1453 & 0.1321 & 0.1187 \\
\hline $25-34$ & 0.1212 & 0.0984 & 0.1060 & 0.0979 & 0.0891 & 0.0831 \\
\hline $35-49$ & 0.1036 & 0.0871 & 0.0834 & 0.0839 & 0.0716 & 0.0736 \\
\hline $50-64$ & 0.1026 & 0.0703 & 0.0871 & 0.0855 & 0.0731 & 0.0687 \\
\hline \multicolumn{7}{|l|}{ Education } \\
\hline Illiterate/Not grad. & 0.1709 & 0.1516 & 0.1724 & 0.1541 & 0.1115 & 0.1173 \\
\hline Primary sch. & 0.1567 & 0.1316 & 0.1283 & 0.1329 & 0.1152 & 0.1211 \\
\hline Middle sch. & 0.1228 & 0.1122 & 0.1295 & 0.1177 & 0.1136 & 0.1057 \\
\hline Gen. high sch. & 0.1177 & 0.0902 & 0.0915 & 0.0938 & 0.0867 & 0.0893 \\
\hline Voc. High sch. & 0.1087 & 0.0973 & 0.1052 & 0.1040 & 0.0983 & 0.0902 \\
\hline Higher Educ. & 0.1201 & 0.1079 & 0.1123 & 0.1027 & 0.0953 & 0.0902 \\
\hline \multicolumn{7}{|l|}{ Sector } \\
\hline Industry & 0.1220 & 0.1126 & 0.1164 & 0.1126 & 0.1046 & 0.1007 \\
\hline Services & 0.1065 & 0.0843 & 0.0884 & 0.0835 & 0.0719 & 0.0719 \\
\hline No. Of Obs. & 3,262 & 3,579 & 2,503 & 3,799 & 3,035 & 5,509 \\
\hline
\end{tabular}

Source: See Table 2 


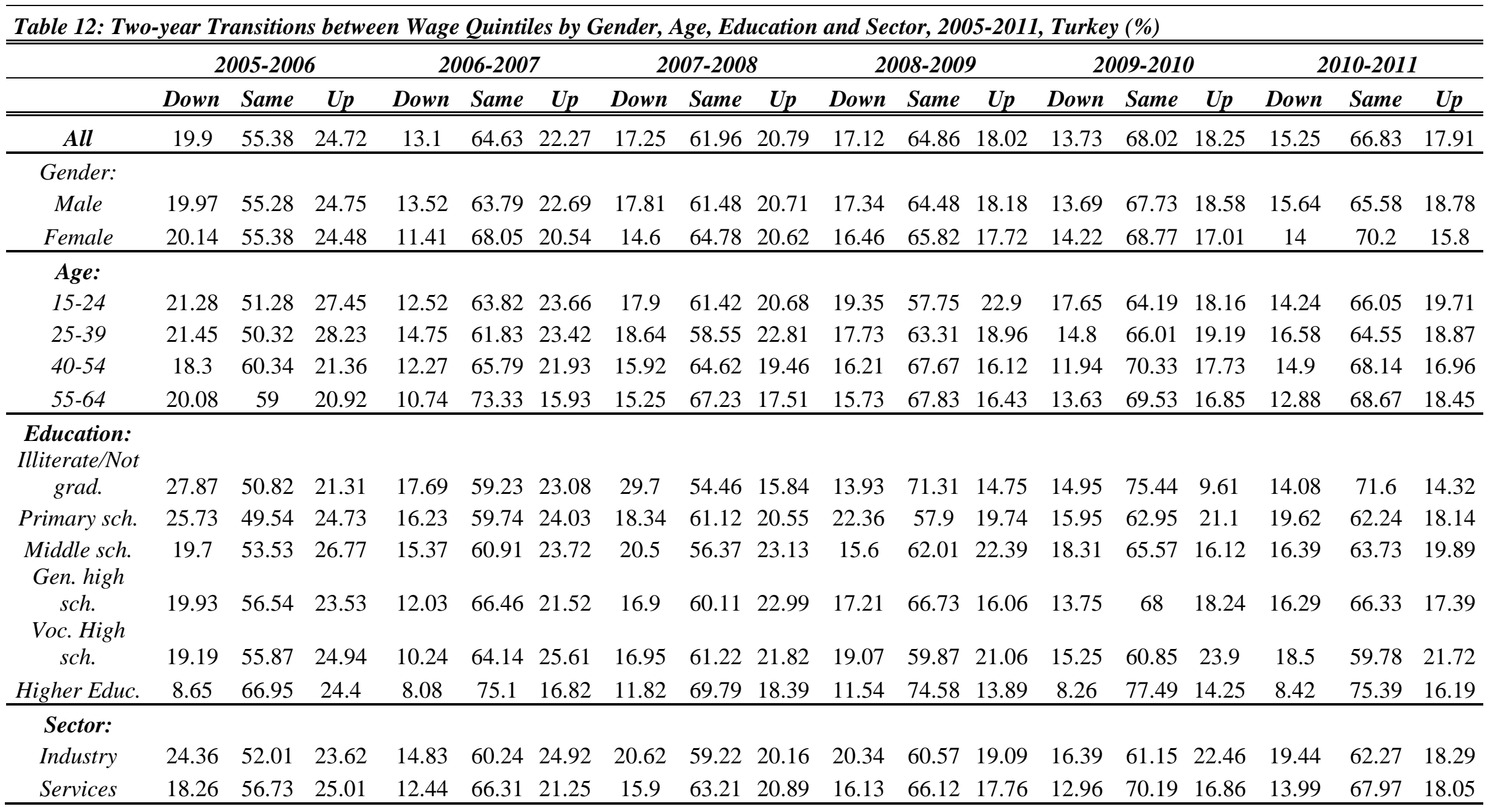


Table 13: Four-YearTtransitions between Wage Quintiles by Gender,Age,Eeducation and Sector, 2005-2011, Turkey (\%)

\begin{tabular}{|c|c|c|c|c|c|c|c|c|c|c|c|c|}
\hline & \multicolumn{3}{|c|}{$2005-2008$} & \multicolumn{3}{|c|}{$2006-2009$} & \multicolumn{3}{|c|}{$2007-2010$} & \multicolumn{3}{|c|}{$2008-2011$} \\
\hline & Down & Same & $U p$ & Down & Same & $U p$ & Down & Same & $U p$ & Down & Same & $U p$ \\
\hline All & 18.05 & 47.51 & 34.44 & 14.2 & 55.17 & 30.63 & 17.61 & 55.94 & 26.45 & 17.62 & 57.69 & 24.69 \\
\hline \multicolumn{13}{|l|}{ Gender: } \\
\hline Male & 18.33 & 47.41 & 34.26 & 14.74 & 54.38 & 30.88 & 19.07 & 53.74 & 27.19 & 19.04 & 56.88 & 24.08 \\
\hline Female & 16.67 & 48 & 35.33 & 12.06 & 58.29 & 29.65 & 10.78 & 66.18 & 23.04 & 12.6 & 60.57 & 26.83 \\
\hline \multicolumn{13}{|l|}{ Age: } \\
\hline $15-24$ & 18.18 & 39.09 & 42.73 & 17.83 & 45.74 & 36.43 & 13.08 & 53.85 & 33.08 & 23.26 & 47.29 & 29.46 \\
\hline $25-39$ & 19.89 & 39.5 & 40.62 & 16.93 & 52.38 & 30.69 & 18.9 & 51.8 & 29.3 & 15.11 & 54.44 & 30.46 \\
\hline $40-54$ & 16.17 & 55.53 & 28.3 & 10.93 & 60.47 & 28.6 & 17.81 & 58.39 & 23.81 & 18.2 & 62.8 & 19 \\
\hline $55-64$ & 18.46 & 60 & 21.54 & 12.24 & 55.1 & 32.65 & 15.94 & 71.01 & 13.04 & 18.06 & 59.72 & 22.22 \\
\hline \multicolumn{13}{|l|}{ Education: } \\
\hline Illiterate/Not grad. & 12.5 & 57.5 & 30 & 40.74 & 37.04 & 22.22 & 21.95 & 60.98 & 17.07 & 32.26 & 48.39 & 19.35 \\
\hline Primary sch. & 26.65 & 41.38 & 31.97 & 19.73 & 46.26 & 34.01 & 23.29 & 52.88 & 23.84 & 28.26 & 46.58 & 25.16 \\
\hline Middle sch. & 14.91 & 52.63 & 32.46 & 20.55 & 45.89 & 33.56 & 19.86 & 50.35 & 29.79 & 19.29 & 57.86 & 22.86 \\
\hline Gen. high sch. & 13.64 & 44.55 & 41.82 & 10.95 & 58.39 & 30.66 & 20.25 & 51.53 & 28.22 & 19.57 & 55.8 & 24.64 \\
\hline Voc. High sch. & 21.77 & 45.16 & 33.06 & 9.68 & 46.77 & 43.55 & 17.69 & 52.38 & 29.93 & 14.88 & 56.55 & 28.57 \\
\hline Higher Educ. & 7.14 & 55.61 & 37.24 & 5.43 & 74.81 & 19.77 & 7.43 & 65.88 & 26.69 & 5.33 & 71.16 & 23.51 \\
\hline \multicolumn{13}{|l|}{ Sector: } \\
\hline Industry & 21.63 & 44.08 & 34.29 & 20 & 50.67 & 29.33 & 21.74 & 48.76 & 29.5 & 27.78 & 46.83 & 25.4 \\
\hline Services & 16.72 & 48.78 & 34.5 & 12.48 & 56.5 & 31.01 & 16 & 58.72 & 25.27 & 14.67 & 60.85 & 24.48 \\
\hline
\end{tabular}


Table 14: Estimation Results of the Multinomial Logit Model of Two Year Transition Dynamics

\begin{tabular}{|c|c|c|c|c|c|c|}
\hline & \multicolumn{2}{|c|}{ Downward Transition } & \multicolumn{2}{|c|}{ No Transition } & \multicolumn{2}{|c|}{ Upward Transition } \\
\hline & Marg. Effect & p-value & Marg. Effect & p-value & Marg. Effect & $\mathrm{p}$-value \\
\hline \multicolumn{7}{|l|}{ Gender (Ref: Female) } \\
\hline Male & -0.030 & 0.000 & 0.000 & 0.959 & 0.029 & 0.000 \\
\hline \multicolumn{7}{|l|}{ Age group (Ref: 15-24) } \\
\hline $25-34$ & -0.036 & 0.000 & -0.036 & 0.002 & 0.071 & 0.000 \\
\hline $35-49$ & -0.097 & 0.000 & 0.007 & 0.549 & 0.090 & 0.000 \\
\hline $50-64$ & -0.080 & 0.000 & 0.013 & 0.425 & 0.067 & 0.000 \\
\hline \multicolumn{7}{|c|}{$\begin{array}{c}\text { Education level (Ref:Illiterate/Not } \\
\text { grad.) }\end{array}$} \\
\hline Primary sch. & -0.016 & 0.170 & -0.072 & 0.000 & 0.088 & 0.000 \\
\hline Middle sch. & -0.043 & 0.000 & -0.077 & 0.000 & 0.120 & 0.000 \\
\hline Gen. high sch. & -0.082 & 0.000 & -0.082 & 0.000 & 0.165 & 0.000 \\
\hline Voc. High sch. & -0.095 & 0.000 & -0.155 & 0.000 & 0.250 & 0.000 \\
\hline Higher education & -0.187 & 0.000 & -0.103 & 0.000 & 0.289 & 0.000 \\
\hline \multicolumn{7}{|l|}{ Sector(Ref: Industry) } \\
\hline \multicolumn{7}{|c|}{$\begin{array}{c}\text { Working Status(Ref: Casual } \\
\text { worker) }\end{array}$} \\
\hline Wage Earner & -0.101 & 0.000 & 0.108 & 0.000 & -0.008 & 0.402 \\
\hline \multicolumn{7}{|l|}{ Year (Ref:2007) } \\
\hline 2008 & -0.050 & 0.000 & 0.077 & 0.000 & -0.027 & 0.000 \\
\hline 2009 & -0.005 & 0.538 & 0.045 & 0.000 & -0.040 & 0.000 \\
\hline 2010 & -0.003 & 0.665 & 0.068 & 0.000 & -0.065 & 0.000 \\
\hline 2011 & -0.027 & 0.000 & 0.094 & 0.000 & -0.067 & 0.000 \\
\hline 2012 & -0.013 & 0.064 & 0.083 & 0.000 & -0.070 & 0.000 \\
\hline Original quintile & 0.083 & 0.000 & 0.013 & 0.000 & -0.096 & 0.000 \\
\hline Pseudo R-sq & 0.0853 & & & & & \\
\hline Num. Of Obs. & 22489 & & & & & \\
\hline
\end{tabular}


Table 15: Fields (2010) Mobility as Equalization

\begin{tabular}{cccc}
\hline \hline & Gini & Theil & MLD \\
\hline $2005-2006$ & 0.0330 & 0.0608 & 0.0815 \\
$2005-2007$ & 0.0324 & 0.0673 & 0.0791 \\
$2005-2008$ & 0.0372 & 0.0774 & 0.0933 \\
$2006-2007$ & 0.0043 & 0.0141 & 0.0188 \\
$2006-2008$ & 0.0142 & 0.0398 & 0.0373 \\
$2006-2009$ & 0.0161 & 0.0597 & 0.0512 \\
$2007-2008$ & 0.0224 & 0.0731 & 0.0519 \\
$2007-2009$ & 0.0459 & 0.1271 & 0.1047 \\
$2007-2010$ & 0.0239 & 0.0642 & 0.0615 \\
$2008-2009$ & 0.0403 & 0.0888 & 0.0903 \\
$2008-2010$ & 0.0211 & 0.0400 & 0.0447 \\
$2008-2011$ & 0.0377 & 0.0853 & 0.0854 \\
\hline \hline
\end{tabular}

Source: See Table 2 
Figure 1: Mean Wages (TL, Base:2003) by Gender, Age, Education and Sector, 2005-2011, Turkey

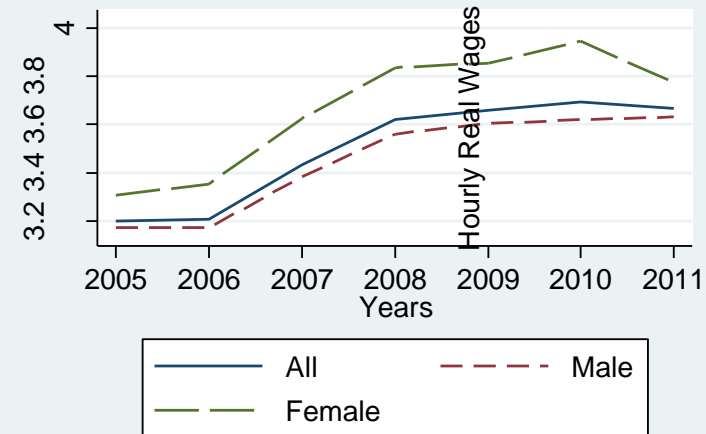

Source: Own calculations using SILC of TURKSTAT
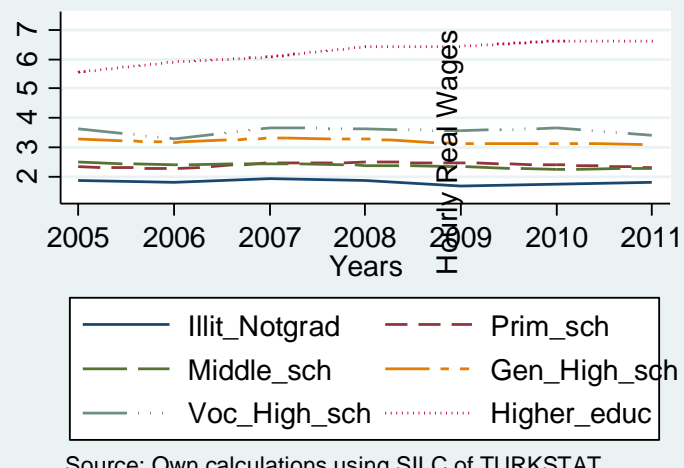
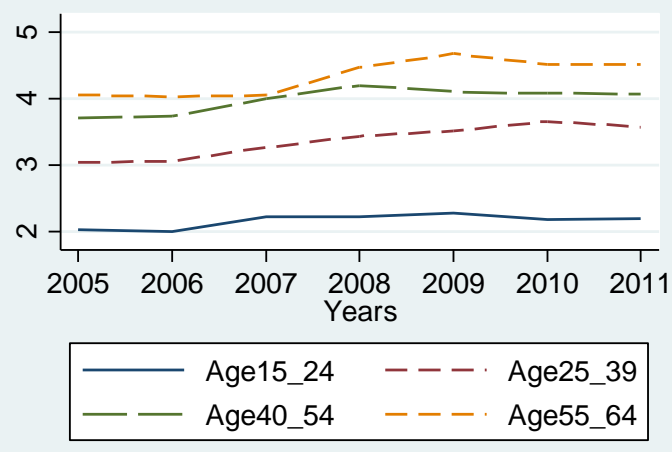

Source: Own calculations using SILC of TURKSTAT

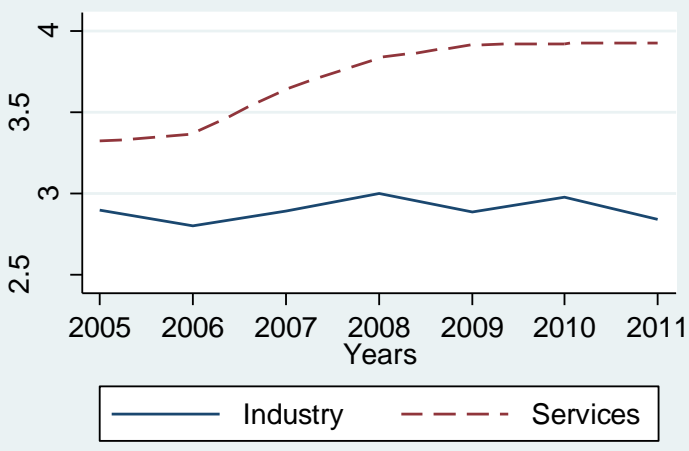

Source: Own calculations using SILC of TURKSTAT 
Figure 2: Mean Hourly Wages (TL, Base:2003) by Gender and Education, 2005-2011, Turkey

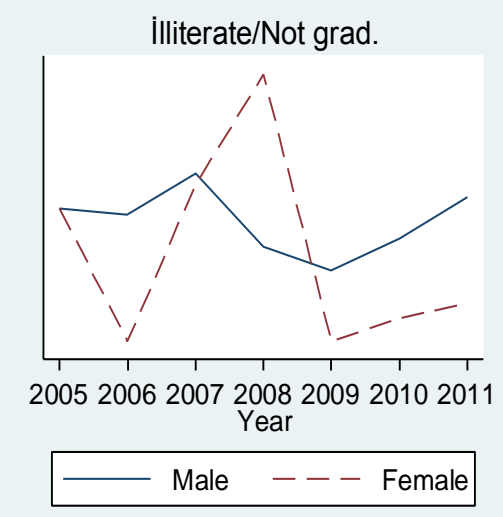

Source: Own calculations using SILC of TURKSTA

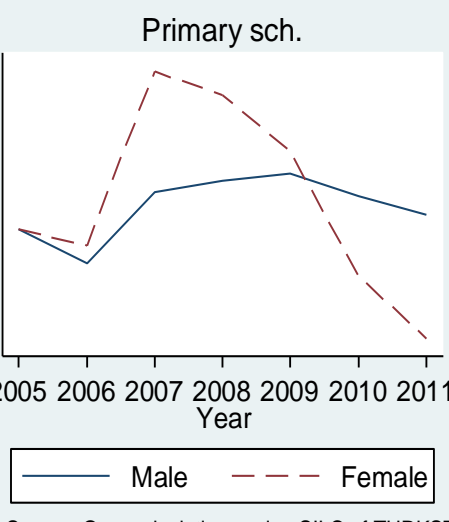

Source: Own calculations using SILC of TURKSTA

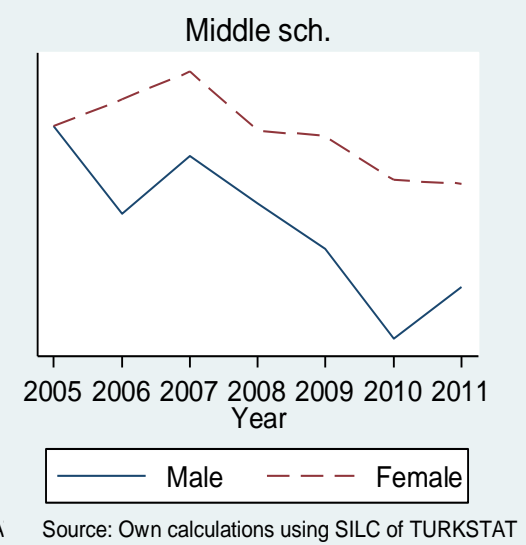

Higher Educ.

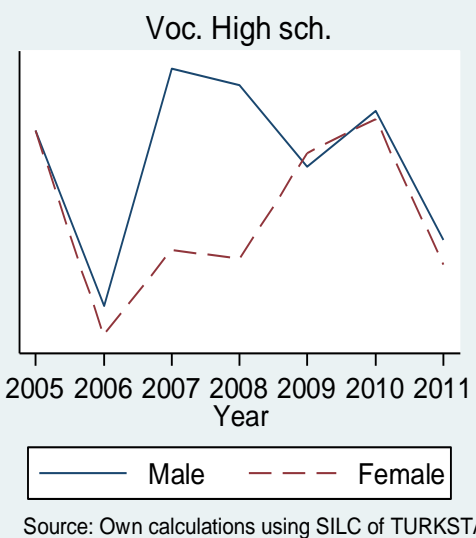

Source: Own calculations using SILC of TURKSTA
Source: Own calculations using SILC of TURKSTAT

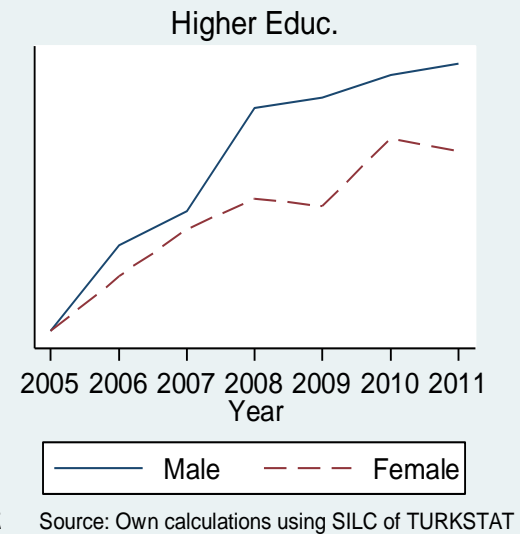

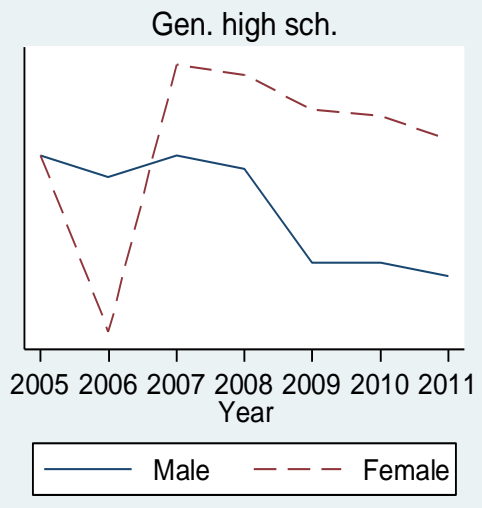

Source: Own calculations using SILC of TURKSTA 
Figure 3: Gini Coefficient by Gender, Age, Education and Sector, 2005-2011, Turkey

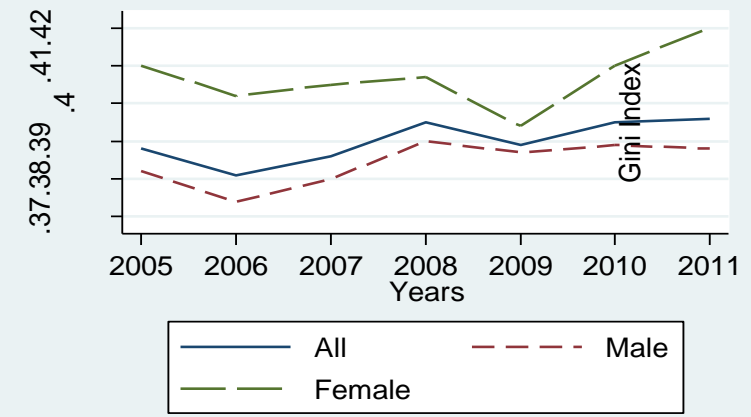

Source: Own calculations using SILC of TURKSTAT

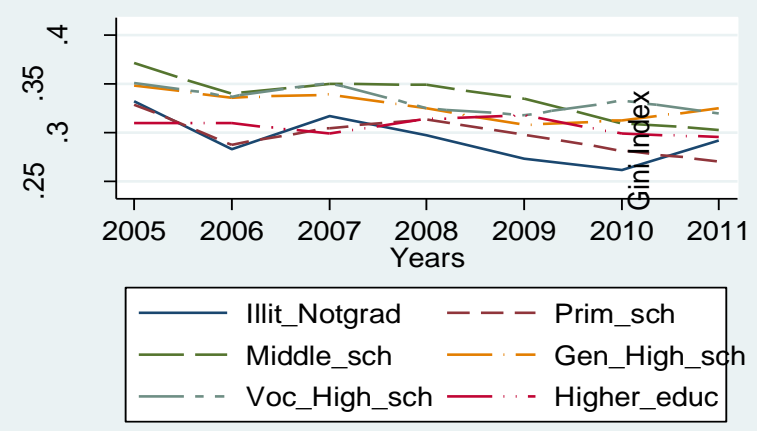

Source: Own calculations using SILC of TURKSTAT

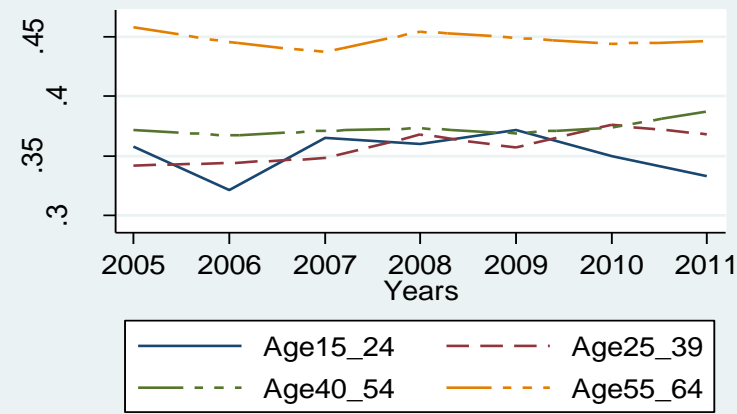

Source: Own calculations using SILC of TURKSTAT

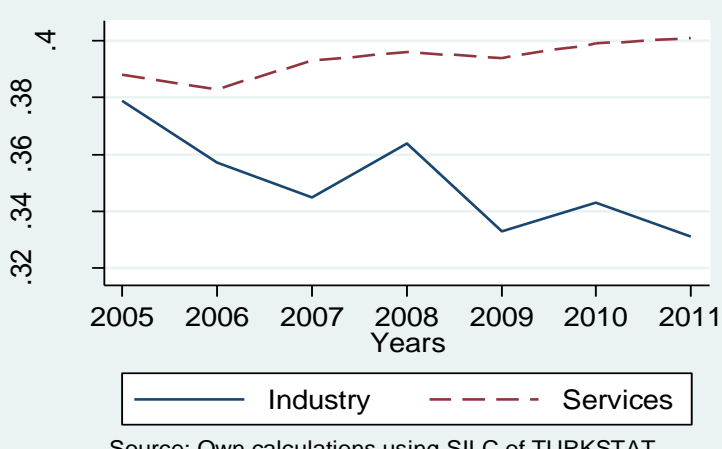

Source: Own calculations using SILC of TURKSTAT 
Figure 4: Theil Index by Gender, Age, Education and Sector, 2005-2011, Turkey

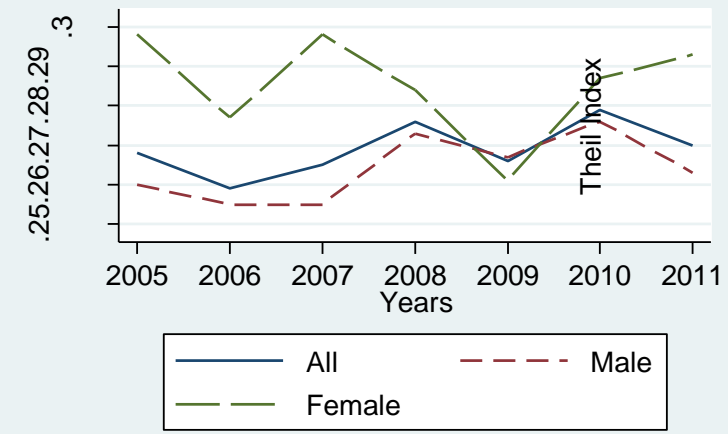

Source: Own calculations using SILC of TURKSTAT

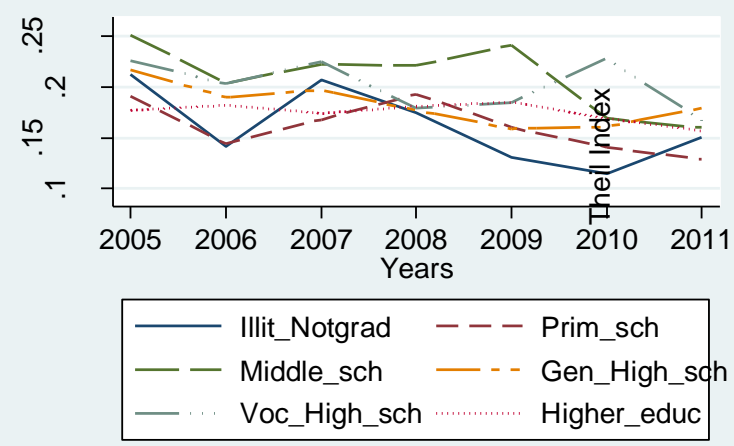

Source: Own calculations using SILC of TURKSTAT

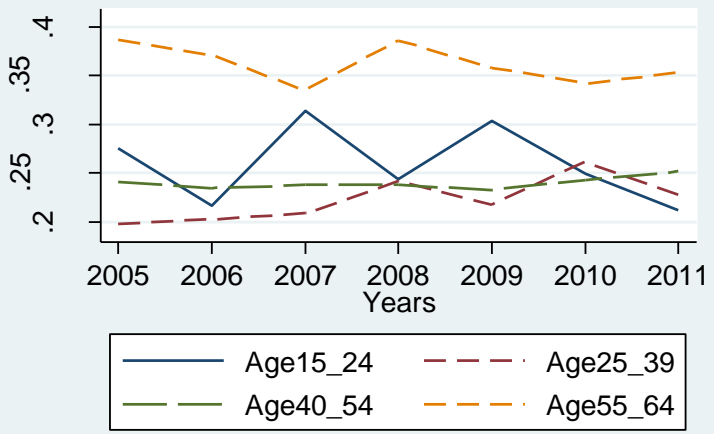

Source: Own calculations using SILC of TURKSTAT

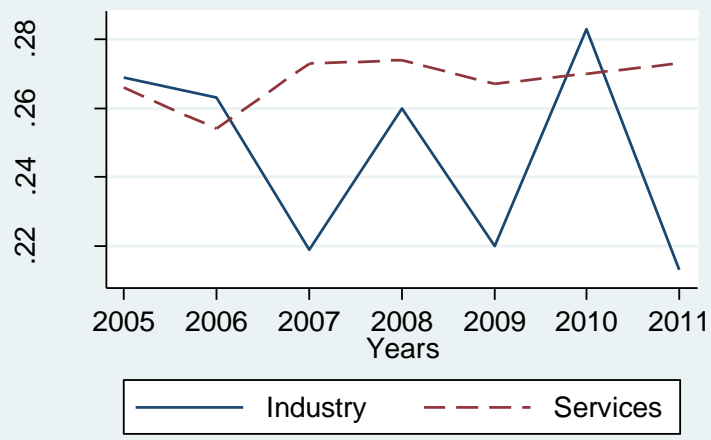

Source: Own calculations using SILC of TURKSTAT 
Figure 5: MLD by Gender, Age, Education and Sector, 2005-2011, Turkey
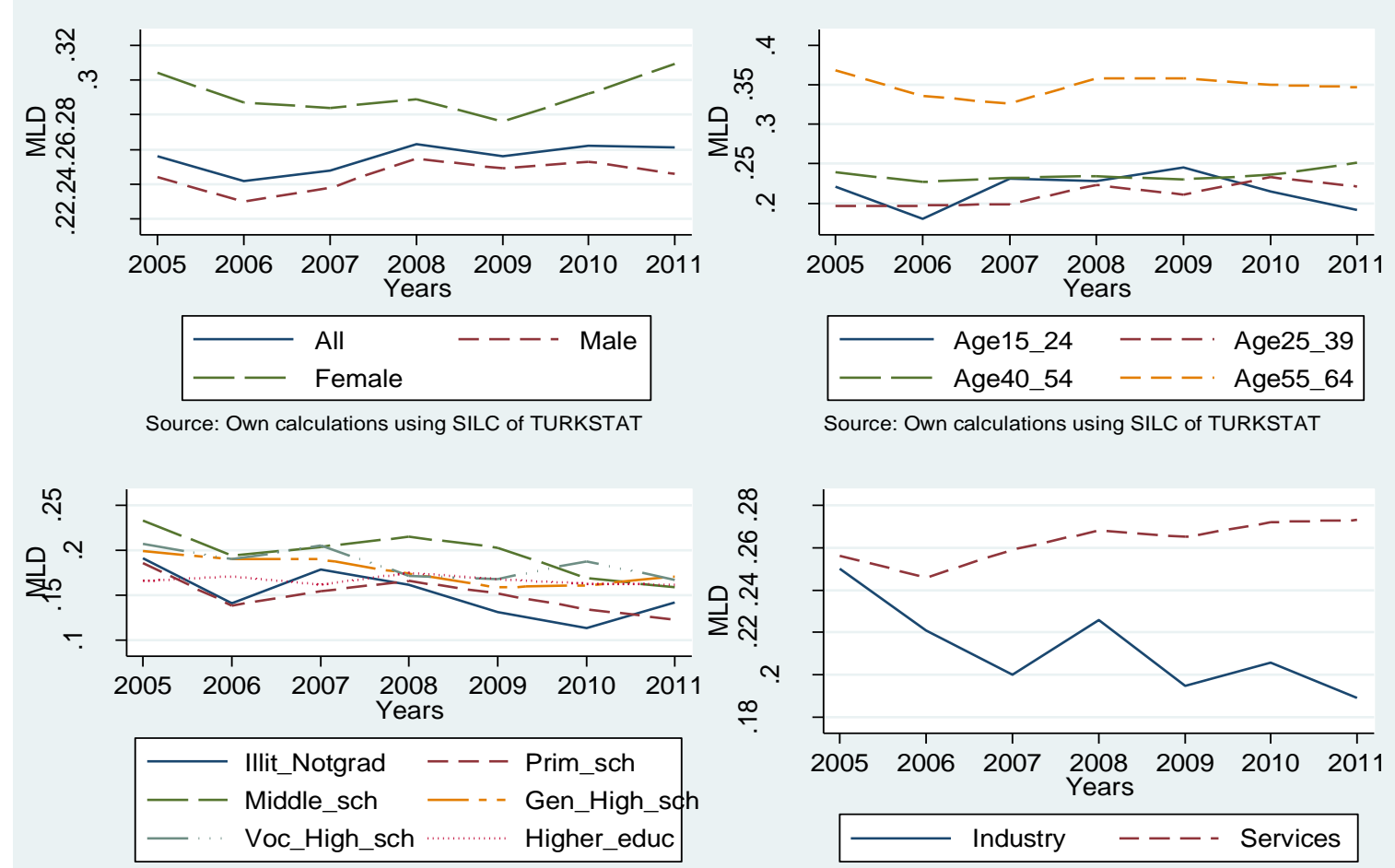

Source: Own calculations using SILC of TURKSTAT

Source: Own calculations using SILC of TURKSTAT 
Figure 6: 90/10 Ratio by Gender, Age, Education and Sector, 2005-2011, Turkey

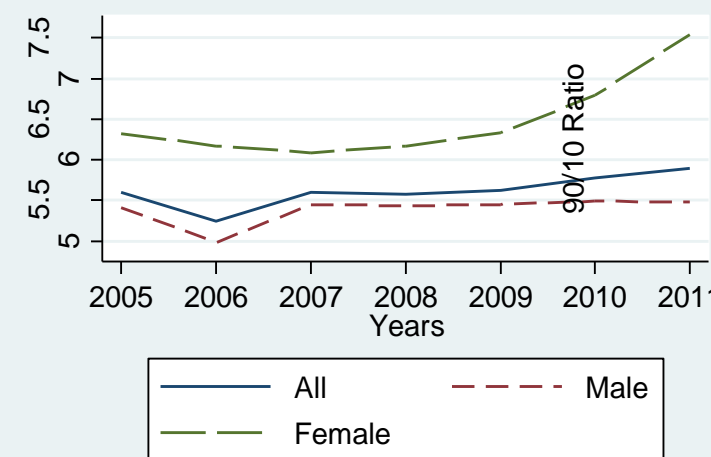

Source: Own calculations using SILC of TURKSTAT
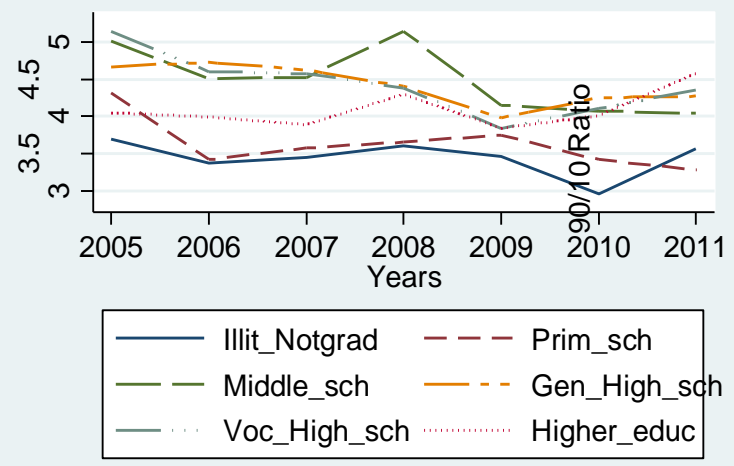

Source: Own calculations using SILC of TURKSTAT
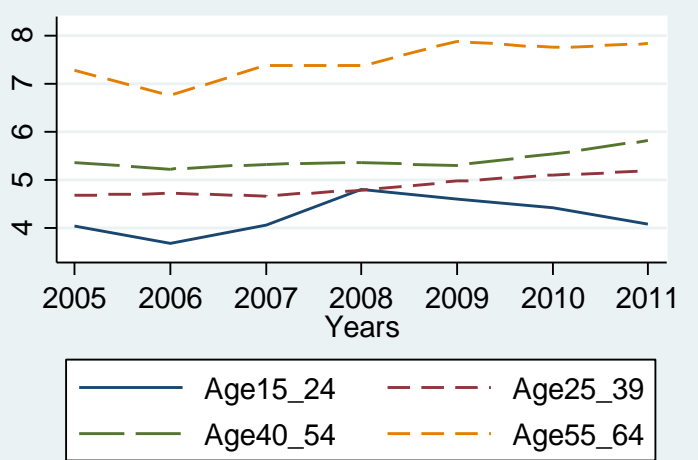

Source: Own calculations using SILC of TURKSTAT

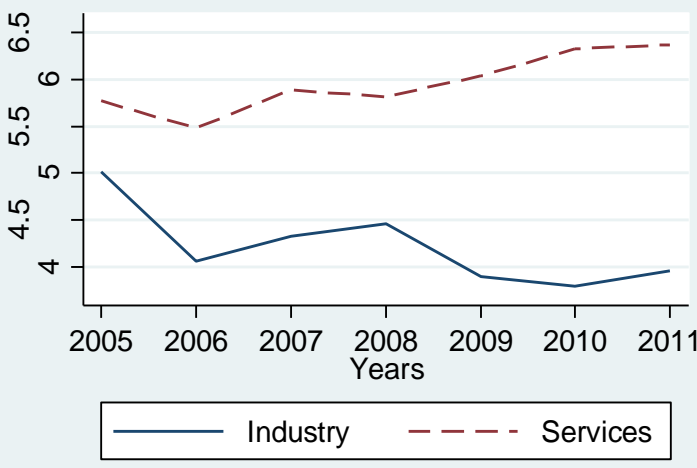

Source: Own calculations using SILC of TURKSTAT 
Figure 7: 90/50 Ratio by Gender, Age, Education and Sector, 2005-2011, Turkey
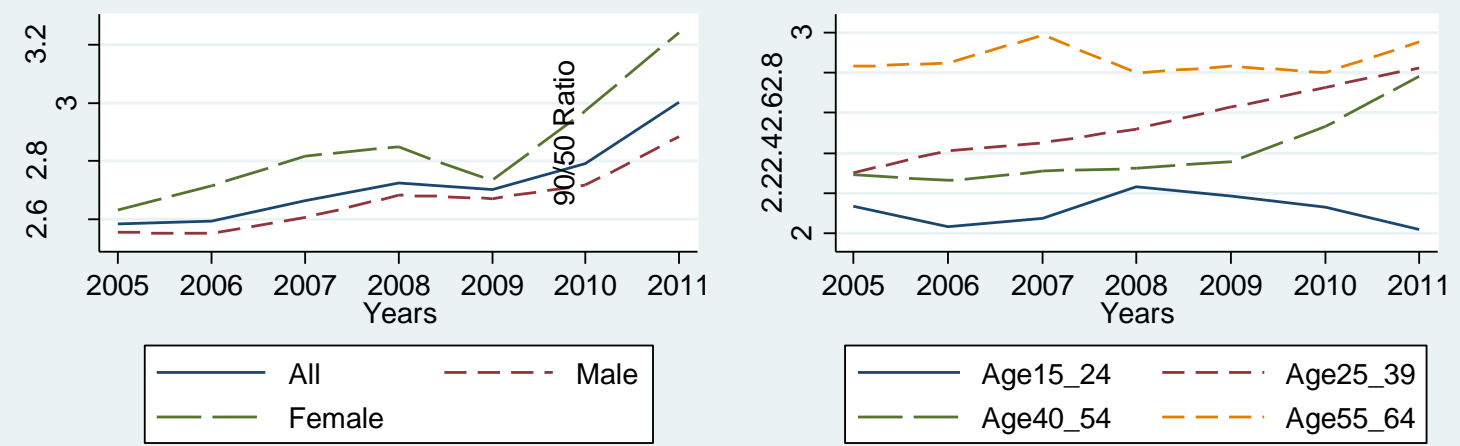

Source: Own calculations using SILC of TURKSTAT

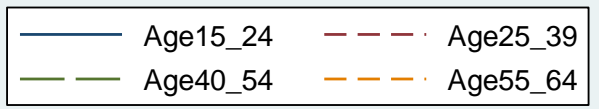

Source: Own calculations using SILC of TURKSTAT
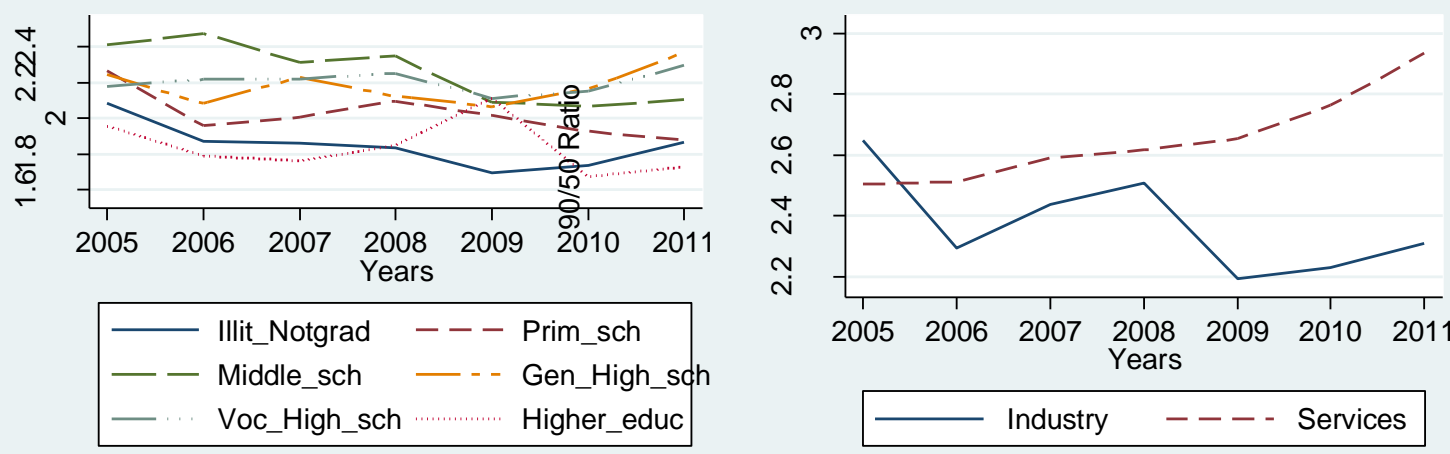

Source: Own calculations using SILC of TURKSTAT

Source: Own calculations using SILC of TURKSTAT 
Figure 8: 50/10 Ratio by Gender, Age, Education and Sector, 2005-2011, Turkey

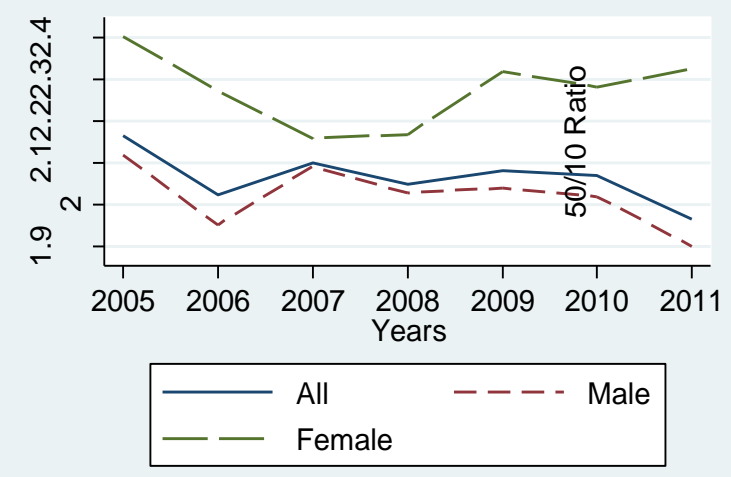

Source: Own calculations using SILC of TURKSTAT

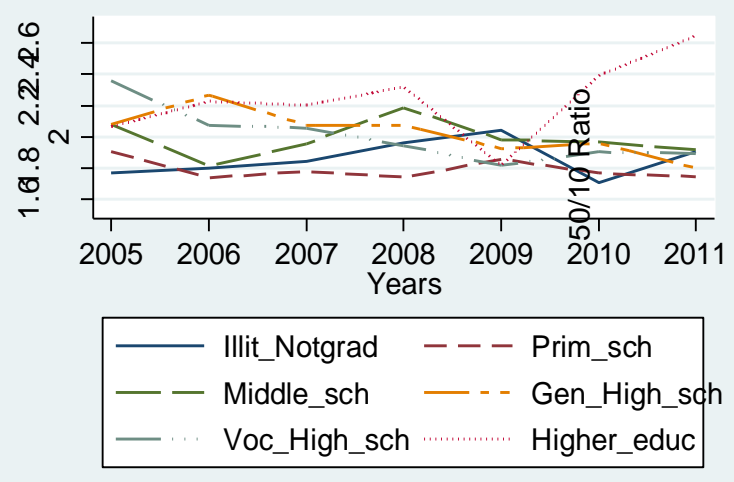

Source: Own calculations using SILC of TURKSTAT

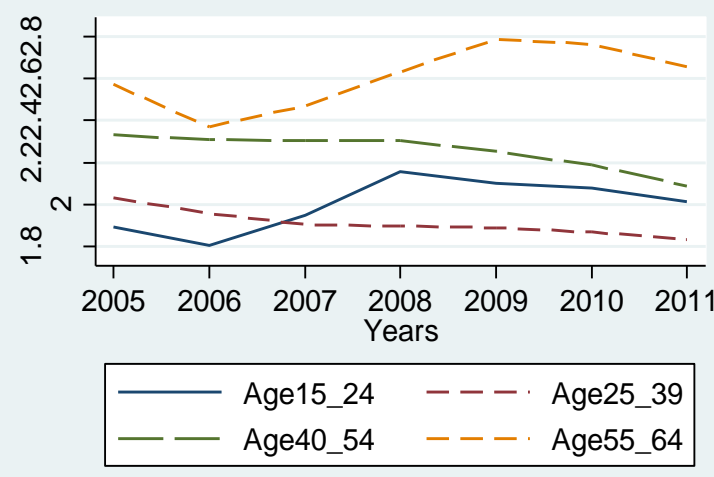

Source: Own calculations using SILC of TURKSTAT

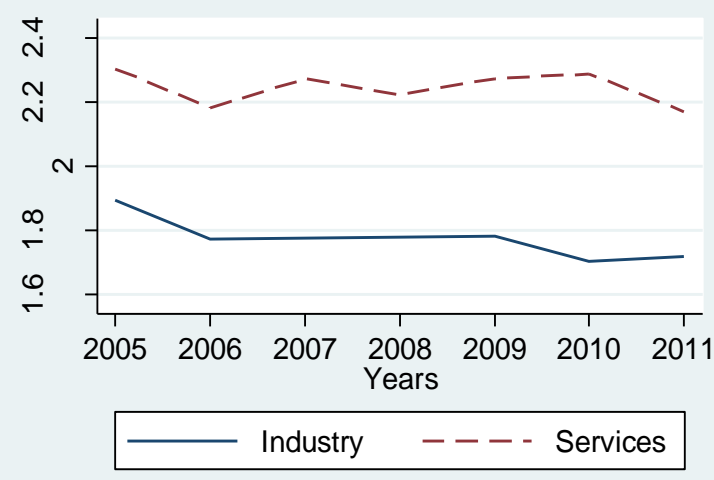

Source: Own calculations using SILC of TURKSTAT 
Figure 9: Various Wage Inequality Measures, Top and Bottom Deciles, 2005- 2011, Turkey

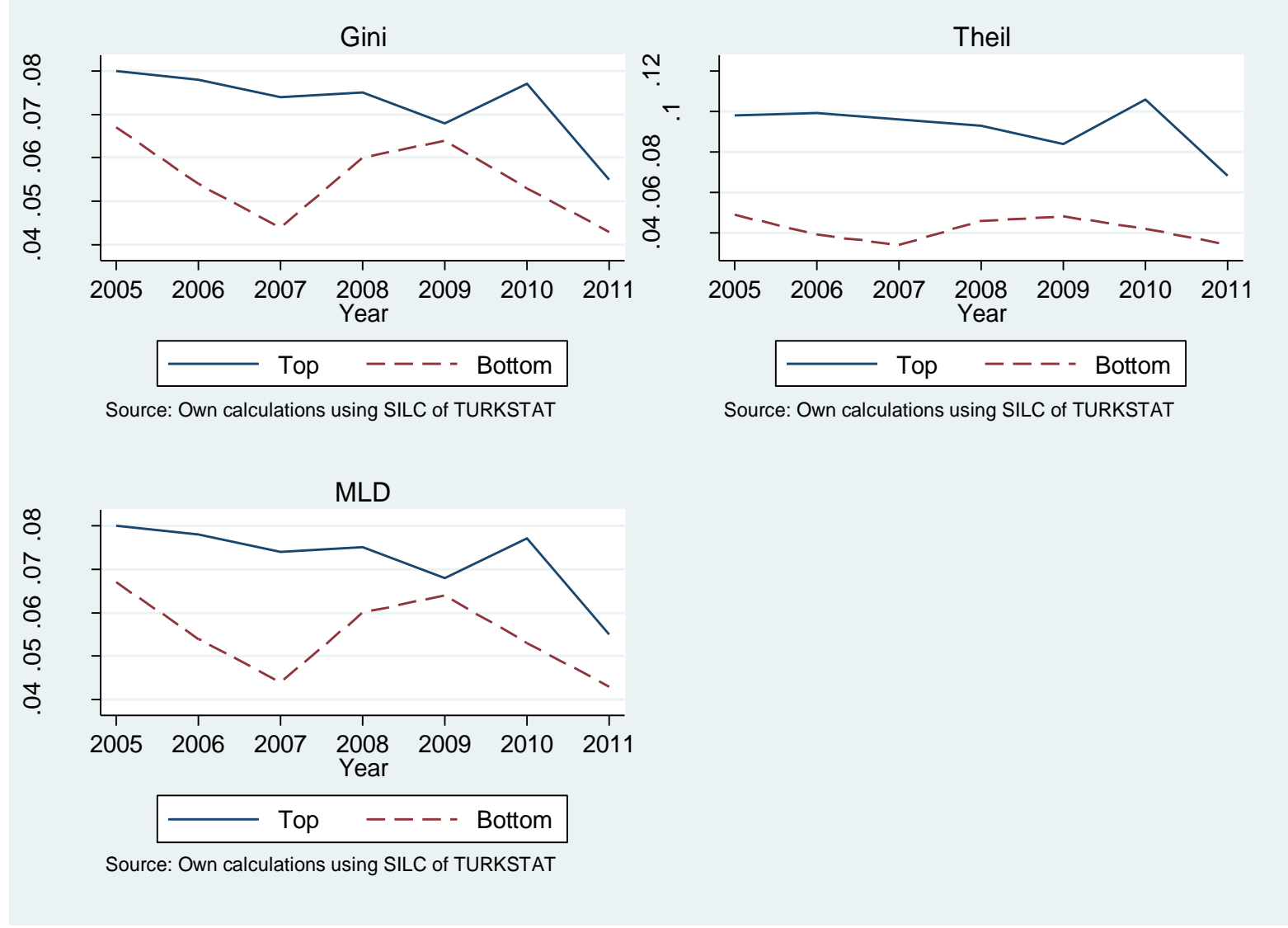


Figure 10: Dickens (2000) Mobility Index by Gender, Age, Education and Sector, 2005-2011,

\section{Turkey}
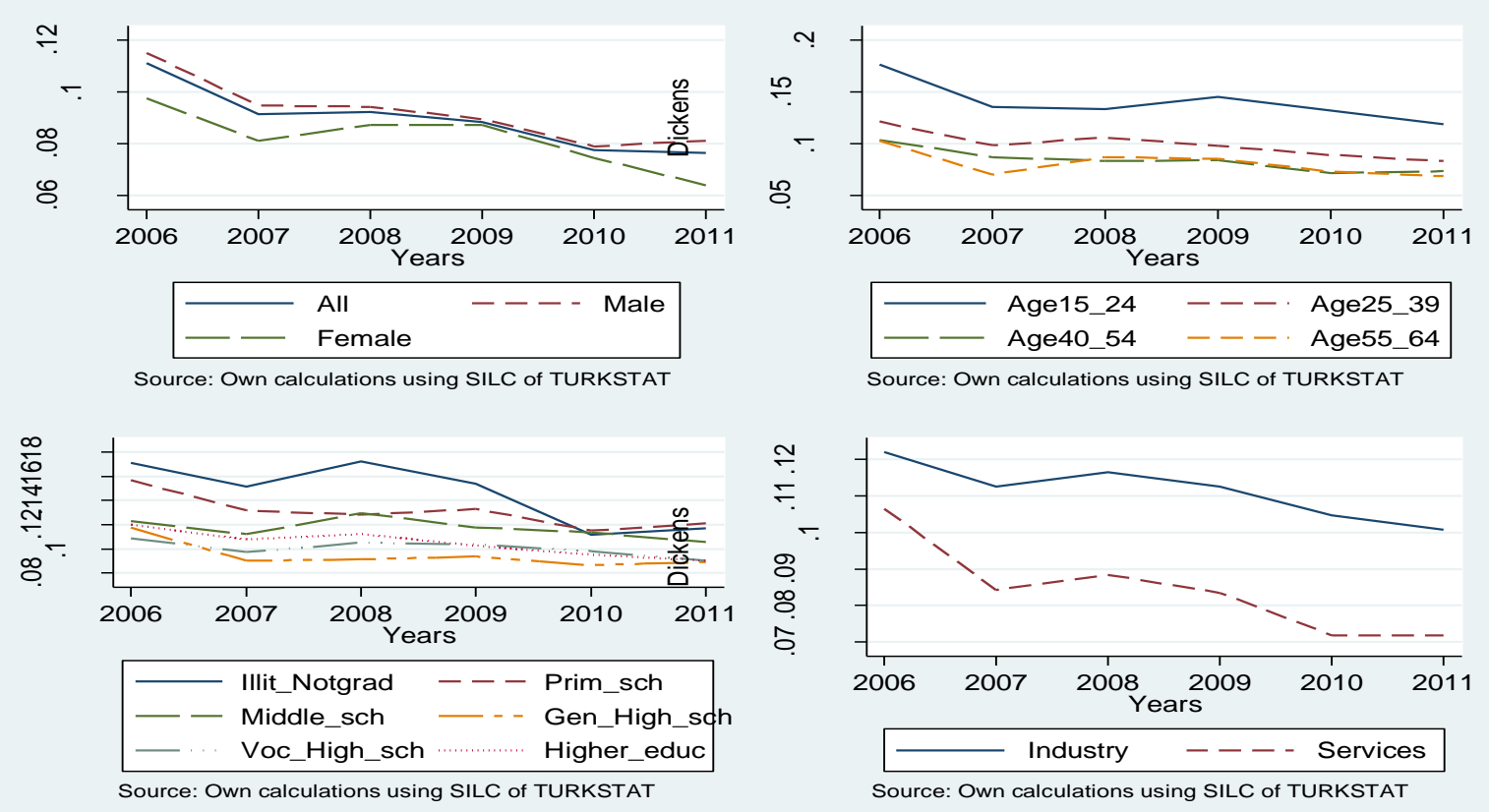